\title{
MEMORIA Y CIVILIZACIÓN
}

ANUARIO DE HISTORIA

\section{$20 / 2017$}

REVISTA DEL DEPARTAMENTO DE HISTORIA,

HISTORIA DEL ARTE Y GEOGRAFÍA

FACULTAD DE FILOSOFÍA Y LETRAS

UNIVERSIDAD DE NAVARRA

Miguel Fernando Gómez Vozmediano

La heráldica del poder: los emblemas de la nobleza española. Realidad y ficción

The Heraldry of Power: the Emblems of Spanish Nobility.

Reality and Fiction

pp. 111-146

DOI: $10.15581 / 001.20 .111-146$ 



\title{
La heráldica del poder: los emblemas de la nobleza española. Realidad y ficción
}

\author{
The Heraldry of Power: the Emblems of Spanish Nobility. \\ Reality and Fiction
}

\author{
MiguEL FERNANDO GÓMEZ \\ VOZMEDIANO \\ Universidad Carlos II \\ mfgvozme@hum.uc3m.es
}

RECIBIDO: SEPTIEMBRE DE 2017

ACEPTADO: SEPTIEMBRE DE 2017

\begin{abstract}
Resumen: Desde la Edad Media ostentar un escudo armas significaba haber conseguido el éxito estamental, evocar el prestigio de una estirpe y visualizar sus méritos en público. Con el paso del tiempo, este signo externo de honra demostró ser eficaz en la estrategia de los linajes para legitimar su ascenso, acrecentar su prestigio, identificar propiedades, alardear de su riqueza, justificar sus actuaciones, proclamar su ascendiente y perpetuar su memoria. En este trabajo mostramos su evolución histórica, su eco en los tratados y en el refranero popular castellanos, así como su representación cultural en la literatura o la emblemática coetánea.

Abstract: Since the Middle Ages, displaying a coat of arms meant to have achieved a high rank in the social status, to evoke the prestige of a lineage and to visualize merits in public. With the passage of time, this external sign of honor proved to be very effective in the strategy of lineages to legitimize their ascendancy, increase their prestige, identify their properties, brag about their wealth, justify their actions and perpetuate their memory. In this work we will show its historical evolution, its echo in the treatises and in the Castilian popular proverbs as well as its cultural representation in contemporary literature.
\end{abstract}

Palabras clave: Nobleza. Heráldica. Emblemática. Historia. Literatura. Abolición del señorío
Keywords: Nobility. Heraldry. Slams. History. Literature. Abolition of Manorialism. 
Buen testigo es el jeroglífico de las insinias, metales y colores destos escudos y buenas partes de que constan; y para prueba de ellas de grande argumento es el motivo que tuvieron los nobles para instituir los escudos de armas de sus linajes, que fue dar a conocer, por medio de ellos, su nobleza, virtud, valor, antigüedad y sus hechos memorables para que en breve epílogo quedase todo informado ${ }^{1}$.

Cuando, a inicios del siglo XIX, Luciano Francisco Comella y Vilamitjana (†1812), periodista y dramaturgo catalán, del círculo del marqués de Mortara y enemigo literario de Moratín, en su cuento «Nobleza. Sueño moral» o «Rasgo moral» caricaturiza las ínfulas desmedidas de la burguesía por ennoblecerse, nos presenta a un personaje obsesionado por su alcurnia. Tras comprar una baronía, pinta su escudo de armas hasta en el retrete y en las herraduras de sus jamelgos; paga con largueza a un genealogista para que haga descender su estirpe de don Pelayo y decora su salón con árboles genealógicos y antiguallas. Además, compra una librería solo para gravar su superlibris heráldico y prestar los ejemplares que pregonasen su estatus; y en la tertulia de su casa solo entraban nobles para conversar sobre asuntos heráldicos y debatían sobre la jerarquía entre las casas reinantes. Ya encumbrado, demuestra su poder castigando a cazadores furtivos y a sus sirvientes. Obcecado por entroncar con alguna casa real, educa a su hija en las leyes del blasón, pero al quedar embarazada de un plebeyo, el protagonista despierta de su pesadi$11 a^{2}$.

\footnotetext{
${ }^{1}$ Fragmento del manuscrito heráldico de Antonio Gómez Arévalo sobre el apellido Salazar, encargado por Cristóbal de Salazar y Sampelayo, vecino de Alcalá de Guadaira (Sevilla); 22-IV-1692, Madrid. Archivo Histórico de la Nobleza (AHNOB), Conquista, caja 3, doc. 27. Curiosamente se trata de un apellido de resonancias conversas (Díaz Rodríguez, 2012).

2 «Soñaba yo que estaba excesivamente rico, y que habiéndoseme trastornado el celebro había comprado la nobleza, agregándola una hermosa tierraja que estaba anexo el titulo de barón. Inmediatamente hice pintar mis armas en las puertas, las ventanas, las chimeneas de palacio: las hice poner en los sombreros de mis criados, en sus medias, en las herraduras de mis caballos. Ni el retrete se libró de ellas; y quería que por todas partes se reconociesen las armas del señor barón. Compré una biblioteca expresamente para poner mi escudo en cada volumen, y los prestaba, a todo viniente, dispensándome de leerlos en atención a mi opulencia. Envié 400 escudos a un genealogista, que me sacaba descendiente de D. Pelayo, por la línea femenina, y el árbol genealógico que colocó en el lugar más a propósito de mi salón» (Comella y Vilamitjana, Nobleza, p. 2).
} 


\section{LA HERÁLDICA DEL PODER: LOS EMBLEMAS DE LA NOBLEZA ESPAÑOLA}

No obstante, también por entonces, Manuel Joaquín Medina, cronista de Carlos IV y rey de armas, certificaba los escudos de armas pertenecientes al I duque de Fernán-Núñez y a su esposa, la duquesa de Montellano, donde se contempla que tales

armas podrán y deberán usar los nominados excelentísimos señores... haciéndolas grabar, esculpir y pintar en sus sellos, anillos, reposteros, tapices, alfombras, coches, libreas, casas, capillas, sepulcros, lucillos, epitafios, cenotafios, plata labrada y demás partes donde bien visto les sea. Entrando con ellas en sortijas, cañas, parejas, torneos y otros juegos permitidos a solo los Grandes, Títulos y Caballeros hijos-dalgo de estos reinos, sin que en ello se les pueda poner obstáculo ni impedimiento alguno por ningún tribunal eclesiástico o secular ${ }^{3}$.

A fines del Antiguo Régimen, muchos coetáneos seguían atrapados en su obsesión por pertenecer a la aristocracia, o al menos parecerlo, y en esta estrategia a largo plazo de todo linaje que se preciase entre los siglos XII al XX, obtener un blasón propio, que proclamara su éxito social, era un elemento clave, un signo de distinción reconocido por todos, que otorgase prestigio y visualizara mediante un código simbólico los méritos y progresos de una estirpe. Un signo externo de honra que demostró ser eficaz en su estrategia para legitimar su ascenso, acrecentar su prestigio, identificar propiedades, alardear de su riqueza, justificar sus actuaciones, evidenciar su ascendiente y perpetuar su memoria.

En este juego de vanidades personales y desigualdades estamentales aceptadas por todos, que condicionan las relaciones sociales verticales y horizontales, blasones, pendones y gallardetes, divisas, adornados con motes, empresas, lemas y alegorías, conforman un universo más o menos erudito, decodificable mediante la retórica de la agudeza que llama Gracián ${ }^{4}$ y que envuelve la e thos nobiliaria.

Además, entre tales creaciones simbólicas y las gentes de la época se estableció un diálogo sensorial, poliédrico, impregnado de connotaciones feudoseñoriales, socioeconómicas e incluso religiosas, perpetuadas durante generaciones. Por ejemplo, quien paseaba por una calle jalonada de piedras armeras se podía meramente recrear con la belleza de sus formas y lo vistoso de sus colores - los blasones solían estar tallados por los canteros con más o menos maestría y luego eran pintados con los

\footnotetext{
${ }^{3}$ 18-VI-1807, Madrid. AHNOB. Fernán Núñez, caja 344, doc. 2, s.f.

${ }^{4}$ Gracián, Agudeza y arte, p. 514.
} 


\section{MIGUEL FERNANDO GÓMEZ VOZMEDIANO}

colores y metales heráldicos-; pero, lo más habitual era que identificase la vía urbana por el nombre de su morador o su mansión más famosa; que le evocase las gestas o la alcurnia de una determinada familia o bien que se ufanase de pertenecer a una comunidad que albergaba sangre tan distinguida. Nada que ver con la óptica de un simple turista actual, que apenas aprecia la epidermis de su estética y desconoce su mensaje, aunque reconozca en ellos su belleza artística y las ínfulas del poder de su dueño 5 .

El objetivo de este artículo será adentrarnos en los recovecos de tales trasuntos del poder para entender su significado profundo y vislumbrar su dimensión como representación cultural; es decir aquellas construcciones mentales que codifican y sirven para (re)pensar nuestra realidad y modular o jerarquizar las relaciones sociales ${ }^{6}$. Con este fin distinguiremos entre la heráldica y su afán de perpetuidad - es decir, los blasones y su corolario de lemas o divisas-; los armoriales - compendios de blasones-; y las arquitecturas efímeras, enigmas, alegorías o empresas -jeroglíficos creados para ocasiones especiales, como fiestas privadas o celebraciones públicas, torneos y juegos de cañas, exequias funerarias, etc. $-{ }^{7}$.

En nuestro entorno cultural, la historiografía decimonónica positivista abordó los estudios heráldicos con un enfoque históricoarqueológico - lastrado por el romanticismo y la revalorización del medievo en clave nacionalista-, siendo el producto más elaborado de su época el nobiliario de Piferrer (1857-1860). En España, en los años centra-

\footnotetext{
${ }^{5}$ «Estas casas de la hidalguía cántabra aguantan colosales blasones. Son fabulosos florecimientos en las paredes desnudas, extrañas erupciones de plasticidad, como tumores de vanagloria que salen a la piedra, virtuosa y ascética. Complacidas en su existencia bien lograda, se ha retirado de las audaces empresas, y en cambio sueñan las antiguas hazañas. Este ensueño heroico de quien ya no es héroe rezuma por los muros en la más ilustre fantasmagoría, y es un trasudar inagotable de heráldica fauna, lobos vizcaínos, ballenas guipuzcoanas, osos de Asturias o bien cimeras de altas plumas, puños con montantes, proas marineras. No es posible dar media docena de pasos sin ser detenidos patéticamente por una pared que nos enseña su bíceps blasonado». Cap. X «Sigue el viaje: Cantabria o ¡venga escudos!» (Ortega y Gasset, 1927, pp. 76-82).

${ }^{6}$ «Cualquier estudio en el campo de los emblemas heráldicos debe comprender dos componentes: sus formas gráficas, por supuesto, pero también sus relaciones con los hombres y con las sociedades que los usan. Y el estudio de estas relaciones es lo más interesante, lo más útil de esos estudios, porque los abren a las relaciones con otras muchísimas disciplinas. Olvidar esta segunda parte conduce a la elaboración de trabajos de índole meramente descriptiva y acumulativa... Quedarse aquí, no pasar adelante, como tantas veces ocurre, es una de las causas del escaso desarrollo y avance de los estudios sobre los emblemas heráldicos». Menéndez Pidal de Navascués, 2008, p.17.

${ }^{7}$ López Poza, 2008b.
} 


\section{LA HERÁLDICA DEL PODER: LOS EMBLEMAS DE LA NOBLEZA ESPAÑOLA}

les del siglo XX se volvió a poner el foco en el patrimonio documental de la aristocracia, espoleado por la adquisición por parte del Estado del Archivo de Bornos (1951), algunas ponencias defendidas en el I Congreso Iberoamericano y Filipino de Archivos (1952), la inauguración de la nueva sede del Archivo Histórico Nacional (1953) y la publicación de algún meritorio tratado nobiliario ${ }^{8}$, junto a la celebración del III Congreso Internacional de Genealogía y Heráldica (Madrid, 1955), potenciaron tales estudios 9 . Mientras tanto, cristalizaron repertorios faraónicos de la talla de los emprendidos por Francisco Fernández de Bethencourt (1897-1920) y los hermanos García Carraffa (1920-1968), continuados actualmente por Endika Mogrovejo; además de los repertorios de Cadenas y Vicent (19641969).

Sin embargo, sería en el último cuarto de la pasada centuria cuando fructificó el giro en los estudios sobre heráldica hacia una historia cultural y un enfoque histórico-antropológico, vinculando emblema a la evolución socioestamental ${ }^{10}$ y una historia cultural de los símbolos ${ }^{11}$, como recogen algunos repertorios de instituciones señeras ${ }^{12}$, si bien predominaron los estudios emprendidos por los medievalistas ${ }^{13}$. En nuestro país, Faustino Menéndez Pidal de Navascués (2014), desde su atalaya de la Real Academia de la Historia y el profesor Fernando Bouza Álvarez (2003), maestro de la historia cultural, han sido los rostros que han capitalizado este cambio de rumbo, siguiendo los pasos de Roger Chartier (1992) y Peter Burke (2001). No obstante, es en el umbral del tercer milenio cuando esta disciplina histórica ha empezado a dejar de ser tabú para los investigadores académicos; hasta el punto de contar con sus propias revistas científicas en el ámbito nacional ${ }^{14}$; inspirar tesis doctorales de

\footnotetext{
${ }^{8}$ Lasso de la Vega, 1951-1953.

${ }^{9}$ Gómez Vozmediano, 2007, p. 144

${ }^{10}$ Pastoureau, 1979.

${ }^{11}$ Pastoureau, 2006.

${ }^{12}$ García Cubero, 1992 y 1995.

${ }^{13}$ Pardo de Guevara y Valdés, 1990.

${ }^{14}$ Publicaciones periódicas como la pionera Revista de historia y de genealogía española (1912-1931); pasando por Hidalguía: Revista de historia y de genealogía española (desde 1953), aferrada a una metodología positivista; hasta llegar a las más modernas Emblemata. Revista Aragonesa de Emblemática (desde 1995); Imago. Revista de emblemática y cultura visual (desde 2009) y la renovadora Revista de Historia y Genealogía (desde 2011), cuyo primer número precisamente versó sobre la imagen del poder.
} 


\section{MIGUEL FERNANDO GÓMEZ VOZMEDIANO}

gran valía ${ }^{15}$, concitar congresos monográficos ${ }^{16}, \mathrm{y}$ vertebrar asociaciones de especialistas.

Con frecuencia tales corporaciones auspician sus propias revistas: la «Real Academia Matritense de Heráldica y Genealogía» (fundada en 1988, publica Anales desde 1991), la «Societat catalana de Genealogia, Heràldica, Sigil.lografia, Vexil.lologia i Nobiliària» (fundada en 1983, patrocina la revista Paratge. Quaderns d'estudis de genealogia, heràldica, sigil lografia i nobiliària desde 1990), «la Institució Catalana de Genealogia i Heràldica» (creada en 2007, realiza la revista electrónica Armoria, desde 2012) y la «Sociedad Española de Emblemática« (creada en 1991, cuenta con la revista Imago, desde 2009). Además, la Universidade a Coruña acoge una plataforma que recopila literatura emblemática hispáni$\mathrm{Ca}^{17}$; aunque, desde luego, nada parecido a la base de datos heráldica existente en Francia ${ }^{18} \mathrm{o}$ las redes internacionales gestionadas por las Universidades de Münster (Alemania) ${ }^{19}$ y Poitiers (Francia) ${ }^{20}$.

Es más, la heráldica se ha convertido en pocos años en un negocio floreciente para eruditos, curiosos, genealogistas y heraldistas, empresas varias $^{21} \mathrm{y}$ hasta desaprensivos, proliferando en la web páginas de dudosa solvencia científica y nula profesionalidad ${ }^{22}$, por no hablar del reclamo turístico que supone y su capacidad para generar ingresos.

${ }^{15}$ Valverde Ogállar, 2004; Valero de Bernabé, 2007; Fernández del Hoyo, 2013; Valle Porras, 2017.

${ }^{16}$ Desde el lejano Primer Congreso de Genealogía y Heráldica (Barcelona, 1929) a los más recientes I Simposio sobre Literatura Emblemática Hispánica (Teruel, 1991), I Congreso Internacional de Emblemática General (Zaragoza, 1999) coordinado por Redondo, Montaner y García López; VI Congreso Internacional de Emblemática organizado por la «Society for Emblem Studies», La Coruña, 2002; y los dos Congresos de Genealogía, Heráldica, Nobiliaria y Ciencias Instrumentales de la Historia celebrados en Santisteban del Puerto (2015 y 2016).

17 «Bases de datos de las obras de emblemática hispánica, bajo Internet» (Universidade da Coruña) por especialistas en Filología española, Historia del Arte y Filología Latina.

${ }^{18}$ La base de datos ARMMA («Armorial Monumental du Moyen Âge»), inventaría y analiza las representaciones heráldicas monumentales medievales conservadas en Francia (entre fines del siglo XII e inicios del XVI).

${ }^{19}$ Denominadas «History of Heralds» o «Heraldica Nova», coordinadas por Torsten Hiltmann, cuentan con la colaboración de investigadores procedentes de 12 países. Disponible: http://heralds.hypotheses.org

${ }_{20}^{20}$ «Devisa. Emblématique et heráldique à la fin du Moyen-Âge», coordinada por Laurent Hablot (Centre d’Études Supérieures de Civilisation Médiévale). Disponible: http://basedevise.edel.univ-poitiers.fr/index.php

${ }^{21} \mathrm{Si}$ rastreamos en uno de los buscadores web más populares las palabras «empresas heráldica» arroja la friolera de 194.000 resultados [26/02/2017].

${ }^{22}$ Olarán Múgica, 1999; Duque de Estrada, 2004. 


\section{LA HERÁLDICA DEL PODER: LOS EMBLEMAS DE LA NOBLEZA ESPAÑOLA}

\section{LA IMAGEN DEL PODER: LOS BLASONES Y LOS LEMAS HERÁLDICOS}

La cultura del Antiguo Régimen es eminentemente oral, gestual y visual, aunque cada vez más es conquistada por la escritura. En este universo, tan complejo como apasionante, se insertan los emblemas y sus derivadas: los blasones, los libros armoriados, las empresas y los lemas, productos culturales imbricados en una civilización caballeresca que cuenta con sus propias reglas y códigos de conducta, y que logran proyectar al resto de la sociedad.

En el plano de la investigación, la metodología de su análisis decantada por los estudios más punteros, parece consensuar que se debería perfilar el modo en el que se han adquirido dichas armerías -inventadas, concedidas por reyes o Papas, armas de enlace (por matrimonio o sucesión de algún título o mayorazgo), usurpadas, etc.-; abordando su análisis heráldico -taxonomía de los símbolos externos-; mapeando sus espacios de representación de las armerías y su difusión geográfica; estudiando la evolución de las armerías dentro de un mismo linaje; indagando el nivel de conocimientos heráldicos y cultura nobiliaria que tenían los personajes que los ostentaron; analizar las coyunturas en las cuales adoptan las armas gentilicias, así como su proyección socioestamental; $y$, por último, investigar qué se conserva y qué se ha perdido en la actualidad de todo este entramado heráldico - visitando lugares de memoria (palacetes, sepulcros, puentes, pósitos), rebuscando objetos domésticos (reposteros, arcones u otros muebles emblemáticos, cerámica, pinturas, armas, sellos y joyas), sin olvidar de indagar en cuantos testimonios escritos $\mathrm{u}$ orales, o fotografías pueda- ${ }^{23}$.

La heráldica tiene sus orígenes más remotos en plena Edad Media, en unas sociedades feudales de frontera volcadas en la guerra, cuyos caballeros comienzan a emplear símbolos o dibujos en sus escudos de armas, para distinguirse tanto en el combate como en las justas o los torneos cortesanos y otras grandes ocasiones que se ofrecían en el servicio de príncipes o magnates. Al menos desde el siglo XII, tales blasones señoriales se heredan dentro del mismo linaje y sus símbolos decoran armas y armaduras, joyas, obras de arte o sepulcros ${ }^{24} \mathrm{y}$ hasta figuras del ajedrez ${ }^{25}$,

\footnotetext{
${ }^{23}$ Valle Porras, 2017.

${ }^{24}$ Arias Nevado, 2006; Menéndez Pidal, 1999, Ferrari, 2015.

${ }^{25}$ Como el famoso ajedrez de la isla de Lewis (Escocia, s. XII), custodiado en el British Museum, cuya piezas portan escudos de armas diferentes. No olvidemos que el ajedrez es un juego de estrategia,
} 


\section{MIGUEL FERNANDO GÓMEZ VOZMEDIANO}

y sus sellos autentifican pergaminos. Las cruzadas extendieron su empleo desde Europa a Oriente Próximo y pronto se identificaron por los profanos en las leyes heráldicas con las familias de poder $\mathrm{y}$, por extensión, con sus apellidos ${ }^{26}$. Todo ello sin olvidar que, en el medievo, predomina en Europa un derecho universal a la adopción y uso de armerías, permitiéndose llevar escudos de armas a los plebeyos, igual que pasa en los reinos hispánicos ${ }^{27}$.

En las coronas de Castilla y Aragón, vínculos o mayorazgos y títulos de nobleza se encuentran unidos indisolublemente desde la Baja Edad Media. Así, durante el reinado Enrique II de Castilla, «el de las mercedes», se heredaba el título según las condiciones establecidas en el mayorazgo, así como la regulación del uso del apellido y las armas por el heredero y poseedor.

A caballo entre el medievo y la modernidad, se vive un tiempo en el cual los nobles se ufanan de su pasado, que suponen de origen visigodo o vinculado a la corte regia, proclaman su protagonismo en la reconquista, en las guerras dinásticas o en la construcción del Imperio; unas gestas - reales o legendarias-que recuerdan, recrean y hasta reinventan, según las circunstancias. La nobleza hispana, ante todo, hace gala de su sangre $^{28}$, de sus méritos y servicios, aunque no es menos cierto que deben su éxito o fracaso a su estrategia matrimonial para unir títulos y patrimonios, así como al buen tino en sus inversiones y a los interminables pleitos en que están envueltos.

En los reinos peninsulares conviven durante el Antiguo Régimen tradiciones diferentes. Si viajamos de norte a sur, en Navarra la heráldica se identificaba con una persona o un palacio o solar y debía registrarse en el «Libro de Armería» regnícola", pero no se corresponde siempre con un apellido sino con unos parientes. En Aragón solo se permitía a los infanzones colocar piezas armeras en sus casas; y en Castilla a nobles, caballe-

\footnotetext{
caballeresco por excelencia y que su tablero se considera un campo de batalla; además, su influencia es mutua, ya que los escaques o el ajedrezado/jaquelado a veces se traspasa a los escudos de armas (Coss y Keen, 2002).

${ }^{26}$ Pues, como recuerda Argote de Molina: «aunque el apellido sea uno, el linaje es diferente», Argote de Molina, Nobleza de Andalucía, «Orden que se ha de guardar en la pintura de los escudos».

${ }^{27}$ Menéndez Pidal de Navascués, 1986.

${ }^{28}$ Ver al respecto García Hernán y Gómez Vozmediano, 2016.

${ }^{29}$ Martinena Ruiz, 1982.
} 


\section{LA HERÁLDICA DEL PODER: LOS EMBLEMAS DE LA NOBLEZA ESPAÑOLA}

ros e hidalgos ${ }^{30}$. Mientras tanto, en Cataluña no era extraño que algunos plebeyos emplearan blasones parlantes sobre su apellido o profesión ${ }^{31}$; algo similar a lo que acontecía en tierras vascas.

Hasta tal punto se identifica nobleza con blasones que una pieza armera a la puerta de una vivienda se convertía en ejecutoria de nobleza incontestada -son los «hidalgos de gotera» o «caballeros de cal y canto» como se les conoce despectivamente-. Así, cuando se exige limpieza de sangre a los candidatos para obtener un hábito de las Órdenes Militares o ingresar en una corporación exclusivista, se consideraba prueba positiva la presencia de un escudo familiar en la casa solariega, la capilla o el sepulcro familiar - los lugares de memoria por excelencia-. Este culto desmedido por tales signos externos honoríficos degeneró en un profuso pleitear ante jueces, tribunales, audiencias y consejos ${ }^{32}$.

En los tiempos modernos, legislación y costumbre reservan los escudos a las elites, en todas sus jerarquías. Así, en 1616, cuando el inquisidor Francisco Blanco de Salcedo funda mayorazgo, a favor de su sobrino predilecto, en su casa solariega en Meneses de Campos (Palencia), la jurisdicción plena sobre sus villas de Castrillana del Río y Villa Obispo y un conjunto de bienes en la villa de Mazariegos (Palencia) heredadas de sus padres impone la siguiente cláusula:

excluyo para la subcesión a bobo, loco, monstruosa, ciego, mudo, fraile, clérigo, monja, beata, persona de religión, salvo de la orden militar que podían casar legítimamente; y así [tam]bién excluyo a el que se casare con persona descendiente de judíos o moros o se casare sin licencia antes de cumplir la mayoría de edad.

Además, obligaba a él y a sus herederos a tomar los apellidos de Blanco de Salcedo y su escudo: «una orla de escaques blancos y negros y

\footnotetext{
30 «Porque deben ser guardadas para Nos las ceremonias reales, mandamos, y defendemos, que de aquí adelante ningún caballero, ni otra persona alguna, puesto que sea constituido en cualquier Título, o Dignidad seglar, no traiga, ni pueda traer, en todos los nuestros reinos y señoríos, corona sobre el escudo de sus armas. Ni traiga las dichas nuestras armas reales derechas, ni por orlas, ni por otra manera diferenciadas, salvo en aquella forma y manera que las trujeren aquellos de donde ellos vienen, a quien fueron primeramente dadas. Ni traigan delante de sí maza ni estoque enhiesto, la punta arriba ni abajo. Ni escriban a sus vasallos ni familiares ni otras personas poniendo el nombre de su pena de la mi merced; ni usen de las otras ceremonias, ni insignias, ni preeminencias a nuestra dignidad real solamente debidas». Cortes de Toledo, 1480. Ley 8, título I, libro IV. Recopilación de las leyes, fol. $249 \mathrm{v}$.

${ }^{31}$ Riquer, 1983.

${ }^{32}$ Gómez Vozmediano, 2015.
} 


\section{MIGUEL FERNANDO GÓMEZ VOZMEDIANO}

dentro de esta orla y circuito tres bandas negras en campo blanco, y en otra tarjeta tres veneras de Santiago en campo rojo con una banda blanca que divida la una de las dos veneras $»^{33}$.

El doble discurso de la nobleza y la fe se funde y confunde en los blasones que se hallan en espacios sagrados, tanto si se trata de escudos episcopales de prelados de alta cuna, como si nos hallamos ante las armas de la estirpe que decoran templos, conventos o sepulcros. Como muestra, en primavera de 1596, la comunidad religiosa de Nuestra Señora del Carmen (Toledo) escrituró un acuerdo con Pedro López de Ayala, IV conde de Fuensalida y consejero de Estado, y su esposa María de Zúñiga y Cárdenas, para reedificar el coro conventual a su costa. De este modo, los aristócratas se comprometieron a pagar a los carmelitas 600.000 maravedís anuales, acordando con Juan Bautista de Monegro, maestro mayor de obras del Alcázar, las siguientes cláusulas:

con condición que en el testero de la cabecera de la capilla mayor que cae hacia el río, se ponga un escudo de armas de piedra berroqueña de seis pies de cuadrado con las armas del dicho señor conde relevadas y con una piedra que diga el letrero: «esta capilla mano redificar el señor don Pedro López de Ayala, cuarto conde de Fuensalida comendador mayor de Castilla e mayordomo mayor del rey don Felipe segundo deste nombre» e más las más letra que a su señoría le pareciere.

Ítem dentro de la capilla, en las pechinas della, se han de poner cuatro escudos de piedra blanca e relevadas las armas de su señoría...

Ítem si su señoría del dicho señor conde quisiere poner otros cualesquier escudos e letreros en la dicha capilla mayor por de dentro e por de fuera, los pueda poner en la parte o partes de la manera e con los letreros que quisiere e fuere su voluntad... a costa del dicho señor conde ${ }^{34}$.

Lo cierto es que entre los ajuares domésticos de los tiempos modernos menudean los objetos decorativo-simbólicos con dibujos heráldicos. Un sondeo aleatorio entre los protocolos notariales toledanos a caballo entre los siglos XVI y XVII nos informa sobre nobles y plebeyos que

\footnotetext{
${ }^{33}$ Canónigo del cabildo catedralicio de Santiago de Compostela e inquisidor de los tribunales del Santo Oficio de Galicia, Murcia y Sevilla; 5-VIII-1616. AHNOB. Conquista, caja 2, doc. 68.

${ }^{34}$ 28-III-1596, Toledo. AHNOB. Frías, c. 859, doc. 37, fol. 11v-12r.
} 


\section{LA HERÁLDICA DEL PODER: LOS EMBLEMAS DE LA NOBLEZA ESPAÑOLA}

atesoran reposteros heráldicos ${ }^{35}$, pero también de criados de aristócratas ${ }^{36}$ y de otros personajes relacionados con el mundo de la cultura escrita que poseen sellos ${ }^{37} u$ objetos varios adornados con escudos ${ }^{38}$. Es lo que algunos han denominado, con acierto, «quiebra de la distinción», al apropiarse los estamentos inferiores de muchos de los signos de distinción de los nobles ${ }^{39}$.

En este sentido, es excepcional el desprecio que demuestra el linajudo Ruy Sánchez Calderón de Celis, cuando a una carta en que se le pedía cuenta de sus armas y genealogía, responde en su misiva que lo más importante era el tiempo inmemorial que los adornaba. Los términos exactos en que escribe son los siguientes:

el blasón ni razón de por que los trajeron los pasados y traemos los presentes no envío, porque además que yo no creo en blasones de linajes y los tengo por contizuelos y hablillas de viejas, basta y sobra la mucha antigüedad y tiempo más que memorial a que tenemos derecho y costumbre de traerlas ${ }^{40}$.

\section{EL DISCURSO DE LA FAMA: LA TRATADÍSTICA HERÁLDICA}

Los armoriales o libros de armería son aquellos repertorios de blasones recopilados por heraldistas, generalmente para regalar o vender a un poderoso o bien para demostrar su vasta erudición y destreza, que pocos aristócratas o caballeros se resisten a coleccionarlos, contemplarlos o exhibirlos ${ }^{41}$.

\footnotetext{
${ }^{35}$ Son los casos, entre otros, de dos viudas: Leonor Dávalos, segunda esposa del señor Melchor Pantoja, quien poseía «dos reposteros con las armas de Ávalos y Toledo» y un tercero con un escudo de los Cervatos [6-XII-1558, Toledo. AHPT. Protocolos Notariales, leg. 1439, fol. 671ss.] y Catalina Ruiz, viuda del mercader Gregorio Hernández, propietaria de cinco reposteros decorados con armas [10 y 26-I-1599, Toledo, AHPT. Protocolos Notariales, leg. 2556, fol. 98r-101r].

${ }^{36}$ En el inventario post mortem de los bienes legados por Antonio de los Reyes, paje de don Pedro de Ribera, señor de San Martín de Pusa y Malpica, se consigna un sello de acero [28-VII-1588, Toledo; AHPT. Protocolos Notariales, leg. 1601, 475r-475v].

${ }^{37}$ Martín Pérez, capellán de la capilla de don Pedro Tenorio en la catedral, era propietario de un sello para lacrar cartas [3-II-1588, Toledo; AHPT. Protocolos Notariales, leg. 1600, f. 336v]

${ }^{38}$ Jerónimo Osorio Quijada, difunto secretario de Bernardo de Rojas Sandoval arzobispo de Toledo tenía entre sus pertenencias un frasco de hojalata con las armas del cardenal [29-V-1608, Toledo ADT, leg. sin catalogar].

${ }^{39}$ Álvarez-Ossorio, 1998-1999.

${ }^{40}$ 3-XII-1573, Valladolid. AHNOB. Torrelaguna, caja 367, exp. sin catalogar, s.f.

${ }^{41}$ Seixas, 2016; Guillén Berrendero, 2016.
} 


\section{MIGUEL FERNANDO GÓMEZ VOZMEDIANO}

Los especialistas han tratado de sistematizar su estudio, clasificándolos mediante criterios codicológicos: según el formato del libro -rollo o, cada vez más, códice_- ${ }^{42}$; el tipo de información que ofrecen -figurada o dibujada; blasonada o descrita con términos heráldicos, siguiendo, más o menos, las leyes del blasón; o mixta, intercalando escudos con explicaciones sobre los linajes representados-; en tanto que otros se fijan en los motivos que los inspiran y su reflejo codicológico ${ }^{43}$ : cuando no glosan algún evento - batalla, alarde, torneo- ${ }^{44}$, representan a los miembros de una cofradía caballeresca o una orden militar $^{45}$, e incluso registran todas las armas gentilicias de un lugar, una región, un reinado o una época, abarcando incluso uno o varios reinos.

En este sentido, un sondeo a los conjuntos armoriados hispanos conservados en instituciones públicas o colecciones europeas y americanas ofrecen una taxonomía desbordante: libros de armería corporativos ${ }^{46}$ o privados ${ }^{47}$; manuscritos -la mayoría-o impresos $^{48}$, e incluso mixtos ${ }^{49}$;

${ }^{42}$ Vaivre y Jéquier, 1975; Neubecker, 1977.

${ }^{43}$ Pastoureau, 1979.

${ }^{44}$ Como plasma el manuscrito de García Alonso de Torres: Protocolo del torneo de Valladolid, 1527.

${ }^{45}$ Libro de Armería de la Orden de San Juan.

${ }^{46}$ Como el Libro de la Cofradía de Santiago (Burgos), compilado entre 1338-1543 (Menéndez Pidal, 1977; Yarza Luaces, 1995), o el rollo armoriado de la Cofradía de San Pablo de Tarazona (1361).

${ }^{47}$ Como el Armorial de los Atondo, manuscrito hacia 1475.

${ }^{48}$ Algunos, como el de Argote de Molina que recoge más de 500 linajes con sus armas y blasones. Dedica todo un capítulo a sus metales y colores: «He querido advertir de la orden que se debe guardar en la pintura de los escudos, que aunque los nobles están obligados a no ignorarlo, solo lo practican los Reyes de Armas, a cuyo cargo toca saberlo. Puse los escudos terciados a la valona, imitando a los libros del cardenal Othon. Las celadas a la mano derecha, porque ninguna puede estar frontera si no es de varón libre no reconociente superior. Los colores de los plumajes han de imitar al color y metal principales del escudo. Si por timbre se pusiere algún animal o ave, ha de ser el mismo del escudo uniéndolo en él. No puede estar metal sobre metal, ni color sobre color. Solo es permitido en el escudo real de Jerusalén, que es la cruz de oro en campo de plata. Los metales son oro y plata. Los colores son cuatro: al rojo llaman gules, al azul blao, al negro sable, al verde sinople. Las aves, animales, peces, y cualquier instrumento, han de tener la frente a la mano derecha. Corona no la puede poner en el escudo sino varón libre, no reconociente superior, si no fuere por gracia particular. Coronel pueden traer los grandes y títulos. Háse de advertir que unos mismos apellidos usan en España de diversas armas, por diversos acaecimientos y causas; y así no extrañe ninguno, si las armas que viere en este libro en su apellido no son las que usa su linaje; que aunque el apellido sea uno, el linaje es diferente: ni menos tenga por malo ningún apellido, porque los que él conoce de aquel nombre sean pecheros, que cosa muy común es en los linajes mas nobles usar del mismo apellido muchos que no lo son, como hoy vemos en los esclavos tomar el de sus amos, y los que antiguamente se convertían a nuestra santa fe, el de sus padrinos» (Argote de Molina, Nobleza de Andalucía, «Orden que se ha de guardar en la pintura de los escudos»).

${ }^{49}$ Precisamente la Fundación Lázaro Galdiano conserva un ejemplar impreso de Argote de Molina con los escudos coloreados a mano. Tal vez sea el que poseía la Universidad de Valencia, mediado 


\section{LA HERÁLDICA DEL PODER: LOS EMBLEMAS DE LA NOBLEZA ESPAÑOLA}

insertados en el libro-becerro o incluso códices devotos de algún linaje ${ }^{50}$, acompañan a cornucopias, retratos al óleo, tratados nobiliarios, genealogías o mapas de Estados nobiliarios. Además, sus escudos pueden estar dibujados, pintados, impresos y recortados... o todo a la vez. También los hay que recogen armerías reales y/o imaginarias - de reinos fabulosos o de novelas de caballerías-; existen armoriales panegiristas o de tachas -libros verdes-, etc.

Se trata pues de unos productos culturales dirigidos, fundamentalmente, a la aristocracia o a los reyes; que se encargan, se regalan y hasta se roban; no siendo menos importante si forman parte de cámaras de maravillas, bibliotecas o archivos; así como dónde se guardan -antecámaras, castillos o palacios propios; colecciones ajenas- $-^{51}$. Siguiendo a los estudiosos de la cultura escrita también sería necesario saber su tradición documental —si existen borradores ${ }^{52}$, si son únicos o se hicieron originales múltiples, si se han copiado total o parcialmente, si fueron escritos o pintados por la misma mano, si está inacabado-; si se han mutilado, corrompido, aumentado o anotado a posteriori; si se conservan de manera contextualizada - con el resto del bagaje escrito de un personaje o linaje- o fueron coleccionados; dónde y quién lo ha confeccionado en origen y a quién iban dirigidos; si el anonimato de algunos es buscado o sobrevenido; a quiénes se mostraban o si se escondían; si se han compilado o despreciado; el precio, en dinero o favores, que se pagó a su autor/autores, por cuánto se tasaron o si terminan en alguna almoneda; su finalidad - si se emplearon en algún pleito de tenuta, para in-

el siglo XIX, regalado por su propio hijo a Argote de Molina, con su retrato dibujado por Pacheco, un resumen de sus servicios, escrito de su puño y letra y los escudos de armas iluminados (Boix, 1849).

${ }^{50}$ Volumen facticio, encuadernado a inicios del siglo XVII, con cientos de páginas que contiene blasones pintados, fragmentos de crónicas copiadas y documentos originales sobre los Ramírez de Arellano AHNOB. Torrelaguna, caja 71, doc. 1.

${ }^{51}$ Casa de Alba: colección llamada Nobiliario de Indias, compuesta por unos 250 privilegios de concesión de Escudos de Armas a conquistadores y ciudades de la América Española durante el siglo XVI. (Calderón Ortega, 2014; López Fanjul de Argüelles, 2015).

${ }^{52}$ Como parece ser el códice intitulado Armas y linajes de los grandes y señores: duques, condes, marqueses, varones de Castilla, León, Aragón, Navarra, Andalucía, Portugal, Valencia, Nápoles y Sicilia que tocan a España y en particular se tratan las sucesiones de estos señores, vecinos y naturales de Sevilla y su tierra y arzobispado (BNE. Mss.1325), con bocetos de los blasones y una explicación de cada Casa, escrito a fines del siglo XVI o inicios del XVII por algún heraldista vinculado a los duques de Medina Sidonia (que es el primero que desgrana, después de el de los reyes) y que perteneció a la librería del marqués de la Romana. 


\section{MIGUEL FERNANDO GÓMEZ VOZMEDIANO}

gresar en alguna corporación exclusivista, como modelo para hacer determinadas obras de arte o simplemente por mero goce intelectual-; qué prestigio tenían en el pasado y si sus dueños lo apreciaban; si se extravió ${ }^{53}$ o destruyó en algún momento; por qué, cómo y por quiénes se ha conservado a los largo de los siglos; el modo de encuadernarlo - de forma funcional, con pergamino, rotulado o no; o bien con piel de becerro gofrada, etc.- si poseen super libris, addendas o notas marginales (rectificaciones, aclaraciones)...

Además, algunos conjuntos heráldicos abandonan el pergamino o el papel y se trasladan a labras pétreas, frescos, rejas, tapices, lienzos, arcones, alfarjes, puertas o jardines de castillos, palacios o templos, e incluso coches de caballos o libreas. Parece como si, acuñado un canon, el modelo se repite una y otra vez, sin importar tanto el medio empleado como el mensaje del poder y el halo de prestigio que transmiten.

Cuentan las crónicas que cuando, en 1525, el III duque de Infantado fue anfitrión del rey Francisco I de Francia, que iba camino de Madrid como rehén a la Corte de Carlos I, al visitar su suntuoso palacio renacentista en Guadalajara ${ }^{54}$ le introdujo en la Sala de los Linajes y se entretuvo en explicarle uno a uno los cien escudos de armas que ornaban la suntuosa sala noble de su palacio, haciéndole ver la gloriosa sangre que corría por sus venas ${ }^{55}$. Tanto fue así que, según los exégetas del Mendoza, el monarca exclamó que «la mayor grandeza que he visto en España de las cosas del emperador es tener tal vasallo como el duque del Infantado». Una heráldica familiar que no solo acrisola el salón más noble de la residencia ducal y que acredita el poder acumulado durante generaciones,

\footnotetext{
${ }^{53}$ Muestra de tales avatares el 8 de noviembre de 1792 en el Diario histórico y político de Sevilla se publica el siguiente anuncio: «El 29 del próximo pasado se perdieron tres Escudos de Armas pintados en papel. A la persona que los haya hallado se le suplica se sirva entregarlos en el almacén de géneros enfrente del Postigo de San Salvador que hace esquina». Diario histórico y político de Sevilla. 9/11/1792, no 70, p. 4.

${ }^{54}$ Jerónimo Munzer opina de este soberbio edificio «No creo que haya en España otro palacio más fastuoso; está hecho para la ostentación, no para la utilidad»; en tanto que el viajero veneciano Andrés Navagero, hacia 1525, describió este palacio del Infantado alcarreño como «el más bello de España (Layna Serrano, 1942; Herrera Casado, 1975).

${ }^{55}$ Parece que cuando el rey francés salía de dicho salón, vio que algunos blasones estaban sin terminar y que, poco más adelante, había un cuadro que representaba una fragua cerca de un molino a la cual se dirigían unas jóvenes; al preguntar su significado, su anfitrión le explicó que las armas pintadas eran las que aún no han sido labradas, los que trabajan en ellos eran los héroes de futuras gestas, las mozas eran las riquezas que les reportarían tales hazañas y el molino riberiego simbolizaba el tiempo que siempre fluye y nunca se detiene (Zapata, 1566).
} 


\section{LA HERÁLDICA DEL PODER: LOS EMBLEMAS DE LA NOBLEZA ESPAÑOLA}

pero que también se proyecta en otros bienes de su propiedad, como arcas, alfombras, bancas, albarelos con remedios médicos o encuadernaciones de libros ${ }^{56}$. Pero también unos blasones que ornan su última morada, fosilizándose en la memoria de muchas generaciones o como pasaporte para su postrer viaje.

Muchos están estudiados de forma particularizada, pero se echan de menos panorámicas de este género áulico, su evolución entre los siglos medievales y modernos, o alguna comparativa entre reinos ${ }^{57}$.

La tratadística heráldica muestra una extraordinaria vitalidad desde la Baja Edad Media hasta el siglo XIX y todavía fascina, bien por la belleza de algunas obras, bien por la rica información que nos aporta, adaptándose a los modos y las modas de cada época. Desde luego, el Renacimiento y Edad Moderna es el tiempo de los tratados heráldicos, por regla general códices panegíricos realizados por eruditos vinculados con los poderes de la época. Destacamos, entre otros, los libros de armerías de Vasco de Aponte (fin s. XV) ${ }^{58}$; Diego Hernández de Mendoza (c. 1495) $)^{59}$; Antonio Agustín (1556) ${ }^{60}$; Sancho Busto de Villegas (hacia 1573) ${ }^{61}$, Gonzalo Argote de Molina (1588) $)^{62}$, etc. Unos tratadistas que claman contra los plebeyos que corrompen tales signos de distinción, pero también contra quienes se ponen las armas reales sin licencia, o contra los que aumentan sus cuarteles haciendo «ensalada en los escudos de sus reposteros, metiendo en ellos todos sus cuatro costados, aun otros linajes con

${ }^{56}$ En el inventario de su ajuar registramos un «arca de noguera grande con dos cerraduras que tenía unos escudos en ellos», tan voluminosa que no se puede mover; «un arca de noguera con tres escudos de armas y dos llaves»; «un arca pequeña de ataraces [¿taracea?] con las armas de Mendoza y un ajedrez en cama»; 24 escudos con los escudos de los Mendoza y 6 con los de Benavente; 5 alfombras con los escudos de los Luna, 3 bancales con las armas de los duques de Benavente y hasta «un calentador con un astil con las armas de Mendoza». AHNOB. Osuna, c. 1832, 2 y 9, s.f.

${ }^{57}$ Menéndez Pidal de Navascués, 2014.

${ }^{58}$ Aponte, 1984.

${ }^{59}$ Blasón de las armas y divisas de los hombres hijosdalgo, inicios XVI, mss.

${ }^{60}$ Agustín, Diálogos de las armas, 1774.

${ }^{61}$ Futuro gobernador del arzobispado toledano, quien por cierto proclama la necesidad de todo noble o hidalgo de saber blasonar y remontar su genealogía por lo menos hasta de su $4^{\circ}$ abuelo y que reflexiona sobre el modo de pintar o dibujar blasones en los objetos. (Guillén Berrendero y González Fuertes, 2014, pp. 203 y 353-363).

${ }^{62}$ De quien se dijo que disfrutó en su residencia sevillana «juntando raros y peregrinos libros de historias impresas y de mano» (Pacheco, Libro de descripción). 


\section{MIGUEL FERNANDO GÓMEZ VOZMEDIANO}

quien alcanzan deudo de manera que los que los ven, conociendo las personas inoran los apellidos» ${ }^{63}$.

Arquetipo de leyenda caballeresca sobre el origen simbólico de los escudos de armas es el elaborado relato sobre el blasón de los Salazar, que hacen remontar su linaje nada menos que al supuesto paladín Lope García de Salazar, cuarto de este nombre:

rico home de Castilla y gran privado de su rey, don Alonso el Sabio, con quien estando en Toledo año de 1260 llegó de África un moro gigante de portentosas fuerzas el que venía a demandar campo a uno por uno a pie, y sabido por los caballeros cristianos que este moro había vencido y muerto trece cristianos en batalla, uno a uno, según constaba por una armejía o marlota colorada que llevaba vestida con 13 estrellas doradas las cuales traía por blasón de haber tenido 13 lides o trofeos con 13 cristianos, y así que combatía a uno augmentaba una estrella dorada en la almejía, por la cual cauza (sic) ningún caballero cristiano obsaba tomar la empresa contra él, y el rey tenía mucho pesar de que no hubiera caballero que le respondiese a la demanda del africano; y cuando vino este moro al dicho desafío, tenía Lope García de Zalazar (sic) 22 años, el cual pidió por merced al rey que le otorgase la batalla contra el bárbaro africano que presente estaba, a que le respondió que le placía y que le encomendaría a Dios y al apóstol Santiago que le diese la victoria, y luego el rey lo armó caballero, y después de haber oído misa lo metieron en un campo serrado (sic). Y Dios, que ayuda a la verdad, y más en tal caso, quiso dar la victoria a Lope García de Zalazar, habiendo durando el combate 6 horas lo mató y cortó la cabeza al moro, y le quitó la almejía que traía de zeda (sic) colorada con las 13 estrellas de oro y tomando la cabeza por los cabellos, y con la otra mano la marlota, se fue a los pies del rey, y le pidió por merced le diese aquella marlota por armas con las 13 estrellas de oro, para sí y para los que de él viniesen, y el rey le respondió que era muy contento pues la había bien ganado, y que era bien empleadas, y le hizo otras muchas mercedes, y por esta razón usan por su escudo de armas en campo colorado 13 estrellas de oro de 8 puntas dejando las antiguas que traían que eran en campo azul una torre de plata rayada de colorado, de cuyo memorable suceso dise Gracia Dei rey de armas de los señores reyes católicos don Fernando $5^{\circ}$ y doña Isabel la copla siguiente tan adecuada a este ilustre apellido y linaje:

En un campo colorado

de oro vi las 13 estrellas

\footnotetext{
${ }^{63}$ Valverde Ogállar, 2004, p. 1030.
} 


\title{
LA HERÁLDICA DEL PODER: LOS EMBLEMAS DE LA NOBLEZA ESPAÑOLA
}

\author{
y un gigante denodado \\ que a morir determinado \\ pasó de África con ellas, \\ a combatir por su ley. \\ Y en Toledo ante el rey \\ lo mató Lope García \\ de Zalazar. Aquel día \\ gran corona dio a su grey ${ }^{64}$.
}

Podría pensarse que condición sine qua non era que tales relatos fuesen verosímiles, pero lo cierto es que circulaban, y se tenían por ciertos, gestas tan descabelladas como el mito de los lagartos monstruosos de la comarca de Quiroga (Galicia), supuestamente exterminados por los Losada y que incorporan a sus armas ${ }^{65}$. En suma, unas fábulas nobiliarias consumidas con avidez por nobles y plebeyos, o lo que es lo mismo, la música del poder orquestada por cronistas, teólogos, académicos, letrados y eruditos, a cuyo son danzan o representan el resto de sus coetáneos y sentencian chancillerías o consejos.

Por otra parte, heráldica y genealogía se convierten en saberes «alquímicos»-que transforman el plomo en oro, es decir, al plebeyo en noble-, solo aptos para los iniciados, es decir, los eruditos privilegiados a quienes se franquea el paso a los lugares de memoria -archivos, bibliotecas, mausoleos, cámaras de maravillas-, o directamente se encargan a quienes saben conjugar las difíciles leyes del blasón. En esta senda, tampoco es casualidad que los jesuitas, consagrados a educar los vástagos de las elites, en su ratio studio rum (1599) o plan de estudios, exaltaran la heráldica en clave de culto al honor, la elocuencia, la pasión por la genealogía, el estudio de la aritmética y la arquitectura y las prácticas cortesanas -como la erudición, la agudeza y el ingenio-o, lo que igual, los pilares de los mayorazgos y las casas solariegas ${ }^{66}$.

En este contexto, es en la Francia del Rey Sol donde el jesuita Claude-François Ménestrier (1631-1705), de vasta cultura cortesana y formación cosmopolita ${ }^{67}$, imprime su profusa obra heráldica y emblemática $(1662,1681,1683,1684,1688)$, de la cual espigaremos tan solo dos

\footnotetext{
${ }^{64}$ AHNOB. Conquista, c. 3, d. 27.

${ }^{65}$ Guillén Berrendero y González Fuertes, 2014, pp. 234-235.

${ }^{66}$ Elias, 1988.

${ }^{67}$ Profesor en los colegios de la Compañía de Chambéry, Viena, Grenoble y Lyon. Entre 1669-1670 viajó por Alemania e Italia, terminando su periplo en la floreciente corte parisina, donde muere.
} 


\section{MIGUEL FERNANDO GÓMEZ VOZMEDIANO}

opúsculos singulares: Le chemin de l'honneur. Jeu d'armoiries (1672) y Le jeu de cartes du blason (1692). El primero es un tablero similar al juego de la oca, dedicado al duque de Baviera, concebido para aprender a blasonar divirtiéndose; representa la mayor parte de las figuras que componen las armerías, con las marcas de honor de las principales dignidades de la iglesia, la toga y la espada, que eran la vías más habituales por las que se adquirían nobleza y blasones. El segundo es una baraja diseñada de tal modo que cada palo es sustituido por una «familia» de escudos ordenados por monarquías; por ejemplo, en el imperio lusoespañol aparecen figuras como los reyes de España y un caballero de Santiago como sota, seguido por otros naipes con escudos de duques, marqueses, condes, barones, caballeros, prelados y ciudades de ambas naciones ${ }^{68}$.

Muy vinculados a los escudos de armas estaban los lemas, frases breves que glosaban las virtudes del cabeza de linaje, sus gestas, origen o ideales, o simplemente aluden a la etimología de su apellido. Por ejemplo, el blasón de la Casa de Solís lleva en su bordura: «Con sol fueron y volvieron y la batalla vencieron». Otros aluden a algún salmo bíblico. Pueden tratarse de lemas latinos ${ }^{69} \mathrm{o}$, cada vez más, castellanos, siendo más raros los escritos en otras lenguas vernáculas ${ }^{70}$.

En abierta puja con otras familias de origen más o menos ilustre, algunos plasman su leyenda o divisa en la bordura - pieza que rodea el interior de un escudo-, o bien la colocan en la parte superior del jefe. La mayoría se enorgullecen de su remoto pasado ${ }^{71}$, su supuesto origen go$\mathrm{do}^{72}$ o mítico -Hércules, Osiris-; vinculan su linaje a la Reconquista -Pelayo o el Cid- ${ }^{73}$ o evocan alguna proeza ${ }^{74}$-por lo general inverosí-

\footnotetext{
${ }^{68}$ Belmas, 2006, pp. 7-20.

${ }^{69}$ «Post nubila, Phoebus», «Después de las nubes, [sale] el sol», reza lema heráldico que orna la encuadernación del nombramiento por Felipe III a Juan Fernández Pacheco, II duque de Escalona como Virrey y Capitán del Reino de Sicilia (1606), AHNOB. Frías, c. 74, d.1.

${ }^{70}$ Alós Fontcuberta, 1961.

${ }^{71}$ «Antes que Dios fuera Dios / y los peñascos, peñascos / los Quirós, eran Quirós/ y los Velasco, Velasco» (un antiguo refrán reza: « [el viento] Nor noroeste y la Casa de los Velasco, señorean La Montaña»), o el lema de los Ibáñez-Pacheco «Estas calderas grabadas / de oro y plata mixtos / fueron aquí pintadas / antes de venir Jesucristo» (Cadenas y Vicent, 1987, p. 888).

${ }^{72}$ «De mi Desiderio godo, del rey Wamba sobrino, procede esta Casa en todo/ por línea recta y camino»; Linaje Alonso (Valle de Valdivieso, Cantabria).

${ }^{73}$ Villegas: «Soy la Casa de Villegas/ que deste alto atalayo / tengo las mis lumbreras, / más antiguas que Pelayo» (Domínguez Ortiz, 1992, I, p. 356)

${ }^{74}$ Se decía de los Pimentel que cuando dejaron de servir al rey de Portugal, se les espeta que más
} 
mil- fosilizada en la memoria del linaje $\mathrm{e}^{75}$. Tampoco faltan las que mencionan al rey o a Dios, figuras dignas de servir ${ }^{76}$, o las invocaciones marianas - nada menos que 19 familias ostentan en el escudo el «Ave María»-. Por último, hay quienes aluden en su lema a los muebles heráldicos que componen su escudo y simbolizan la personalidad de su antepasado común ${ }^{77}$.

Como ocurre con la multiplicación de los cuarteles de los blasones, conforme pasan los siglos, los lemas de algunas estirpes se hacen cada vez más largos. Como muestra, en el siglo XVII, la asturiana casa de Castrillón ostentaba esta letanía:

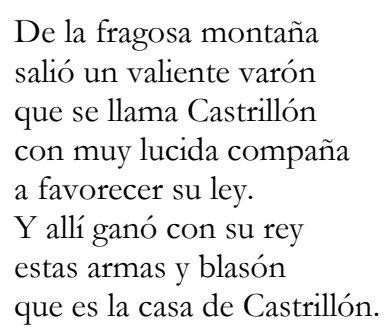

El discurso de la fama también se plasma en empresas y emblemas. En ocasiones, como justas o torneos, los paladines empleaban motes (máximas) o empresas (jeroglíficos). Tal imagen simbólica iba aparejada a la hazaña que se pretendía conseguir, glosada en el lema de alguna prenda de la que se hace alarde, si bien ya en la corte de los Austrias los motes también eran frecuentes en los juegos palaciegos y los cortejos galantes $^{78}$. Es precisamente por entonces cuando el cronista Gonzalo Fernández de Oviedo escribe el primer tratado de empresas hispanas, donde se nos dan muchas pistas de las costumbres cortesanas y la moda de tales jeroglíficos o alegorías:

vale pájaro en mano que ciento volando, es decir que era muy aventurado cambiar de señor; sin embargo el caballero les responde a los cortesanos «más vale buitre volando».

75 «Después de Dios/ la Casa de Quirós» y ornan su escudo las llaves de San Pedro, evocando una mítica ayuda de la Casa a los papas (Velasco Maíllo, 2007).

${ }^{76}$ «Deo et regis» de los Osuna o del III duque de Alba; o «Mas pesa el rey que la sangre» de la Casa de Guzmán (duques de Medina Sidonia).

${ }^{77}$ Como la Casa de Caldea (Durango): «Las armas de mi nación / lobos y calderas son», simbolizando los lobos el ardor guerrero o la valentía y las calderas la rica-hombría.

${ }^{78}$ López Alemany, 2009; Silva y Mendoza, Obra completa. 


\section{MIGUEL FERNANDO GÓMEZ VOZMEDIANO}

He suélense poner estas divisas en los costados de los escudos fuera dellos con una letra que determine su significación e algunas veces acierta a ser tal la divisa o invención de no haya menester letra; he que del nombre solamente o significado della se comprende la causa e motivo del que la trae; pero donde se pone letra u mote que es mejor en este caso, e que no sea villancico o canción como muchas veces hacen por inadvertencia [...] al propósito de las divisas lo mas breve es lo mejor e si se pudiese en una palabra demostrar la significación e misterio muy más linda cosa es e de más ingenio ${ }^{79}$.

Asistimos, pues, a cómo en los siglos modernos nace, o por lo menos se desarrolla, la literatura visual ${ }^{80}$ cifrada en enigmas, acertijos, insignias, divisas, símbolos o poesías mudas, que se crean para mascaradas de Corte, fiestas aristocráticas, certámenes urbanos, justas poéticas, exequias $^{81} \mathrm{u}$ otros acontecimientos fastuosos. Por ejemplo, para agasajar a Pedro Girón, III duque de Osuna, flamante virrey de Sicilia, Giacomo Saporiti escribió en 1611 un panegírico donde aparecía la imagen de un basilisco bajo el lema «pro sibilo fama», que pretendía evocar su fama de justiciero granjeada en Flandes, cuyo solo nombre aterrorizaba a traidores y malhechores, como hacía el basilisco con el común de los mortales ${ }^{82}$.

Los emblemas son creaciones morales eruditas, típicas de los humanistas pero que se desarrollaron extraordinariamente en el Barroco, cuando hallan en el grabado - suelto o como ilustración libraria-su medio ideal de difusión ${ }^{83}$. Muchas de estas alegorías estaban arquitrabadas en los lemas heráldicos y la iconografía simbólica clásica o los epigramas romanos, que solían ilustrar portadas de libros aleccionadores, ornar impresos religiosos, engalanar cronicones familiares y panegíricos, personalizar muebles o tabaqueras, o decorar la arquitectura efímera: arcos triunfales, túmulos funerarios, visitas de señores a sus villas y vasallos, etc. ${ }^{84}$ Con cierta frecuencia, tales emblemas trascendieron a las bellas artes y la literatura ${ }^{85}$.

\footnotetext{
${ }^{79}$ Carrillo Castillo, 1998-1999, p. 143.

${ }^{80}$ López Poza, 2011.

${ }^{81}$ Escalera Pérez y Galindo Blasco, 2000.

${ }^{82}$ López Poza, 2008a.

${ }^{83}$ Mínguez, 1999; Lozano López, 2014, p. 69.

${ }^{84}$ Rodríguez de la Flor, 1995; Rico, 1990.

${ }^{85}$ Praz, 1989; Zafra y Azanza, 2000; Oteiza, 2002; Egido, 2004; Ortiz Rodríguez, 2012; Esteban Llorente, 2010; Arellano, 2013.
} 


\section{LA HERÁLDICA DEL PODER: LOS EMBLEMAS DE LA NOBLEZA ESPAÑOLA}

Llama poderosamente la atención que en los colegios de la Compañía de Jesús se fomentase la «pedagogía del ingenio», dentro de la cual la heráldica y la literatura emblemática fue un instrumento esencial en su didáctica ${ }^{86}$.

En este fárrago de emblemas heráldicos y lemas, los reyes de armas $^{87}$ empezaron a actuar como notarios regios, acreditando que un linaje podía ostentar un determinado blasón, desautorizándolo en caso contrario y haciendo picar las piedras armeras en último extremo ${ }^{88}$. Por eso, un rey de armas de Carlos II recordaba que:

los señores Reyes Católicos don Fernando y doña Isabel, quintos abuelos de vuestra majestad dieron providencia sobre este punto de los coroneles, y escudos de armas, comprendiendo la observancia de la mejor, y mas regular práctica del arte haráldica, que se halla establecida en todos los reinos y naciones políticas de Europa, según los preceptos y reglas derivadas de gente en gente, que por universal consentimiento, y por conveniente policía, dejaron a cargo de los reyes de armas, haraldo, farautes o pasavantes (que con todos estos o semejantes nombres son conocidos) el declarar, enmendar, o determinar las dudas, que cada día se ofrecen sobre la forma en que se deben esculpir, pintar, o bordar los escudos de las armas reales, y de cuantos, según su dignidad, estado y nobleza, pueden usar de armas, blasones y empresas en los palacios y edificios públicos, para su adorno de sus casas particulares, sepulcros, epitafios, estandartes, pendones, banderolas, cotas, libreas y reposteros, instrumentos que sirven al aparato militar, a el lustre de la corte, y a el mayor lucimiento de las ceremonias que se celebran en la presencia de vuestra majestad y de su palacio y corte ${ }^{89}$.

Y, más adelante, afirmaba que

así dentro, como fuera desta corte (en cumplimiento de las reales órdenes de vuestra majestad, y de su Consejo), he quitado, borrado, picado, y desencajado escudos, y cuarteles, a personas, que, o por su corta calidad les está prohibido ponerlas, o no estar conforme a reglas de armería, o tener

\footnotetext{
${ }^{86}$ Beltrán-Quera, 1984; Labrador, 1992.

${ }^{87}$ Algún especialista aventura que existe esta figura en la corte desde 1580 (Ceballos-Escalera y Gila, 1993, p. 112).

${ }^{88}$ Ceballos-Escalera y Gila, 1992-1993; Guillén Berrendero, 2009, 2010, 2013a, 2013b, 2015a, 2015b y 2016.

${ }^{89}$ Guerra y Villegas, Discurso, 1693, fol. 4r-4v.
} 


\section{MIGUEL FERNANDO GÓMEZ VOZMEDIANO}

yerro conocido en ellas, usando de la potestad que pide, y les es permitido a los reyes de armas de vuestra majestad ${ }^{90}$.

3. LA REPRESENTACIÓN CULTURAL DE LA HERÁLDICA: LITERATURA, PRENSA Y OPINIÓN PÚBLICA

Unos signos de distinción tan difundidos como los blasones y los lemas no pasaron desapercibidos a sus coetáneos, que los ensalzan o vituperan, según el caso, pero que no dejan indiferentes a nadie. No obstante, su eco literario apenas ha suscitado investigaciones sistemáticas, salvo la tesis pionera de McCready (1962).

Los escritores españoles del Siglo de Oro y del Barroco, siempre cercanos al mecenazgo nobiliario ${ }^{91}$ e impregnados de la cultura del honor coetánea -baste recordar la osadía de Lope de Vega al estampar en La hermosura de Angélica, 1602, su escudo de armas con las 19 torres de los Carpio- $-{ }^{92}$, mencionan los blasones como emblemas que prestigian, glosan, prueban y publican la buena sangre de sus dueños. Unas armas que hay que venerar, honrar, defender, obtener ${ }^{93}$ o condenar, como el escudo de la orden de Calatrava, que recordaba al maldito comendador de Fuente Ovejuna, cuyo oprobio merece que sea arrinconado por el escudo real en el drama de Lope de Vega (vv. 1922-2126).

Incluso se acuña en la España de los Austrias el subgénero de las comedias de armas y linajes ${ }^{94}$. De este modo, la palabra blasón aparecerá en un buen ramillete de obras teatrales barrocas: Lope terminó en $1599 \mathrm{El}$ Blasón de los Chaves de Villalba en casa de los condes de Chinchón, aunque la publica en 1618, y poco después hace lo propio con La corona merecida y blasón de los Coroneles (1603-1620). El blasón de los Alvarados, ideada por Antonio de Morales, fue estrenada en Lima en 1621. Vélez de Guevara pergeña Más pesa el rey que la sangre o el blasón de los Guzmanes - a mayor honra de don Gaspar de Guzmán, conde-duque de Olivares, cuya prosapia hace remontar hasta Guzmán el Bueno- o Si el

\footnotetext{
${ }^{90}$ Guerra y Villegas, Discurso, 1693, fol. 61r.

${ }^{91}$ Zugasti, 1998.

${ }^{92} \mathrm{Y}$ la furibunda reacción que despierta en sus rivales literarios: Góngora y Cervantes, quienes se burlan de su vanidad y tornan sus torres en molinos de viento o en torreznos, aludiendo al cargo que tenía su suegro como abastecedor de carne.

${ }^{93}$ Como en Lope de Vega, El blasón de los Chaves de Villalba (1618) y El blasón de los Guzmanes, o defensa de Tarifa de Antonio Zamora [Universidad de Sevilla, Fondo Antiguo, mss. A250/081(4)].

${ }^{94}$ Riguet, 2015.
} 


\section{LA HERÁLDICA DEL PODER: LOS EMBLEMAS DE LA NOBLEZA ESPAÑOLA}

caballo os han muerto y Blasón de los Mendozas; Rojas Zorrilla dedica la última jornada de Los tres blasones de España a Rodrigo de Vivar en una época en que los Mendoza recuperan al Cid como antepasado de su estirpe y es el nombre de pila del VI duque del Infantado ( $\$ 1657)$. Agustín Moreto es autor de la comedia El blasón de los Moncadas (c. 1648); el dramaturgo Juan Claudio de la Hoz y Mota ( $\uparrow 1714)$ es autor de la comedia el Abrahan castellano y Blasón de los Guzmanes; en tanto que es también a esta pujante Casa a quien dedica su comedia de enredo Antonio Zamora El Blasón de los Guzmanes o La defensa de Tarifa.

Sin duda, el tono encomiástico predomina en comedias, entremeses y poemas ${ }^{95}$. Paradigma de los loores que merecen los escudos de la aristocracia son las lisonjas vertidas por Calvete de Estrella a los Lecca en $\mathrm{La}$ Corsica $^{96}$ o el soneto dedicado por Góngora al conde de Lemos, famoso mecenas y bibliófilo, cuando visita Monforte en $1609^{97}$. Algo parecido ocurre con Lope en La Arcadia, donde dedica un soneto fúnebre a Gonzalo Girón, jugando con la homonimia de su apellido y blasón: «Aquí yace el maestre de Santiago, / que a España de un jirón dejó vestida / de gloria y honra que inmortal se llama» ${ }^{98}$. El mismo Fénix de los Ingenios, en su comedia El Primer Fajardo. Crónicas y leyendas dramáticas de España, describe según las leyes heráldicas las armas de los marqueses de los Vélez, oriundos de Santa Marta de Ortigueira (Galicia): «yo tengo en campo de oro / tres matas de ortigas verdes. / Siete hojas cada mata / hace el blasón mi solar, / sobre tres rocas del mar / con ondas de azur y plata». Nuestro prolífico dramaturgo, en el poema épico-narrativo Jerusalén conquistada (1609), también alude a «los Moncadas / las armas de sus troncos laureadas»; halago que reitera en La hermosura de Angélica, cuando unos de sus personajes exclama «Cataluña empieza luego / con las armas de Moncada $»^{99}$. Lope parece no dejar aristócrata sin halagar cuando dedica el siguiente soneto a los Portocarrero: «iOh tú, casa de Palma siempre ilustre, / de blasones heroicos adornada/ y por tu mismo

\footnotetext{
${ }^{95}$ Zugasti, 1998, pp. 129-157.

${ }^{96}$ Díaz Guito, 2014.

97 «Llegué a este Monte Fuerte, coronado / de torres convecinas a los cielos, / cuna siempre real de tus abuelos, / del reino escudo, y silla de su estado... / ¡Oh cuánto deste monte imperioso / descubro! Un mundo veo. Poco ha sido, que seis orbes se ven en tu divisa»; estando su escudo amueblado con torres y roeles (orbes) (Zugasti y Cortijo Ocaña, 2015).

${ }^{98}$ Pedraza Jiménez, 1993, I, p. 300.

${ }^{99}$ Trambaioli, 2009, pp. 10-11.
} 


\section{MIGUEL FERNANDO GÓMEZ VOZMEDIANO}

nombre esclarecida! / Vive segura, que inmortal el lustre de tu timbre es». Aunque en su obra La Arcadia deslice su opinión de «Que las armas heredadas / aunque tengan real valor, / no pueden dar tanto honor / como las que son ganadas», participando del debate entre sangre o virtud que contamina los discursos sobre nobleza de la época. Incluso el histriónico Quevedo no se resiste a elogiar al todopoderoso valido de Felipe $\mathrm{IV}^{100}$.

En otras ocasiones, dramaturgos y novelistas recurren a la emblemática para reforzar su narración y ambientar la escena. Por ejemplo, Castillo Solórzano, en el bachiller Trapaza, nos transporta a un torneo, donde un duque llevaba «puestos por empresa, un bordón de plata y encima un lucero grande de plata», cuya divisa rezaba: "Yerra aquél que peregrina / sin aquesta luz divina»; en tanto que su contrincante, acudió a la justa con ocho músicos y cuatro padrinos «vestidos todos de tela riza azul con alamares de plata, color que era de Laudomira... y por empresa un sol cercado de lucientes rayos, y decía la letra: "Cobarde es quien se retira, / puesta en vos siempre la mira" $\gg^{101}$.

Por supuesto, tampoco faltan a alusiones que identifican armas con apellidos ${ }^{102} \mathrm{y}$ en las comedias abundan las citas a los godos como antepasados míticos o a don Pelayo ${ }^{103}$ y al Cid como referentes genealógicos de muchas familias de poder ${ }^{104}$, sumergiéndose algunos autores en el doble discurso de la nobleza y la santidad ${ }^{105}$.

En este contexto oligarquizado, los villanos también gozan de sus propios blasones, como son la honradez, la limpieza de sangre y el orgullo de vivir trabajando. Así, previendo lo que habría de pasar, Peribáñez, a la vuelta de la romería a la Virgen del Sagrario (Toledo), orgulloso por

\footnotetext{
100 «Y si os dio el ascendiente generoso / escudos, de armas y blasones llenos, / y por timbre el martirio glorioso, / mejores sean por vos los que eran buenos / Guzmanes, y la cumbre desdeñosa os muestre, / a su pesar, campos serenos». Quevedo, «Epístola satírica», p. 137).

${ }^{101}$ Castillo Solórzano, 1637, pp. 158-159.

102 «El apellido es blasón / que califica linajes / que diferencia sujetos / que autoriza antigüedades» (Tirso de Molina, El amor médico, vv. 600-604).

103 «Pelayo, rey de Asturias, / que Dios siglos luengos guarde, / para blasón de los godos / e pavor de los alarbes» (Vélez de Guevara, El alba y el sol, vv. 3128-3131).

${ }^{104}$ Vega García-Luengos, 2007, pp. 49-78.

${ }^{105}$ Es el caso, por ejemplo, de Tirso de Molina, quien escribe la hagiografía de santa María de Cervellón, primera religiosa mercedaria, profesa en la misma orden redentorista que el autor, en cuyo proemio a Barcelona asegura que es «hija de esa nobilísima ciudad, rama de una de las mas ilustres y antiguas casas de su Principado... que merece con sus flores coronar sus barras, por lo calificado, lo santo, lo milagroso, lo útil y lo todo». El hológrafo de esta obra en BNE. RES/150, p. 11.
} 
ser un campesino «de buen pasar» quiere devolver el repostero que decoraba el carro de romero, poniendo en su boca las siguientes palabras (vv. 989-1001):

\author{
Pienso que nos está bien \\ que no estén en nuestra casa \\ paños con armas ajenas; \\ no murmuren en Ocaña \\ que un villano labrador \\ cerca su inocente cama \\ de paños comendadores \\ llenos de blasones y armas. \\ Timbre y plumas no están bien \\ entre el arado y la pala, \\ bieldo, trillo y azadón; \\ que en nuestras paredes blancas \\ no han de estar cruces de seda ${ }^{106}$.
}

En todo caso, la recompensa de gozar de un blasón es tan importante que solo se contempla renunciar a tal privilegio para alcanzar mayor fortuna o servir a otro rey más alto. Es el caso del duque de Gandía, que ingresa en la Compañía de Jesús y llega a ser su general, muriendo en olor a santidad, como recogen los versos lopescos en La vega del Parnaso ${ }^{107}$.

Pero el Siglo de Oro, periodo crítico para la aristocracia ${ }^{108}$, también deja espacios para la crítica, el sarcasmo, la trasgresión. Lo fácil era criticar de manera abstracta los excesos de linajistas, genealogistas y heraldistas; así, Lope, siempre inclinado a los poderosos recurre a las fábulas con animales parlantes y crea la ficción del gato Micifuf, cuyos bigotes destilan vanidad, quien proclama sus armas a quienes quieren oírle:

desciendo, como tengo en pergamino

pintado de colores y oro fino

\footnotetext{
${ }^{106}$ En esta senda, Tirso de Molina en su trilogía hagiográfica concebida para contribuir a canonizar a Santa Juana, pone en boca su pretendiente este alegato de los villanos: «Yo, aunque cristiano viejo, en sangre limpio, / soy labrador; mi casa y sus paredes / (en vez de los tapices que en las vuestras adornan) / se contentan con vestirse / de cedazos, arneros y de trillos, / y los doseles que mis techos cubren, / horcas de ajos, pimientos y cebollas» (Tirso de Molina, Quinta parte de comedias, esc. IX, acto 1 ).

107 «dejó del timbre la corona de oro / generoso blasón de sus mayores». Lope de Vega, La vega del Parnaso, II, vv. 14-15.

${ }^{108}$ Stone, 1985; García Hernán, 2000.
} 


\title{
MIGUEL FERNANDO GÓMEZ VOZMEDIANO
}

\author{
por armas un morcón \\ y un pie de puerco de Zamora \\ ganados en el cerco, todo en campo de golas, \\ sangriento más que rojas amapolas, \\ con un cuartel de quesos asaderos, \\ róeles en Castilla los primeros (Egido, 1996, p. 27).
}

En tanto que Cervantes desmitifica los libros de caballerías en el Quijote, cuando hace participar de sus desvaríos «al siempre vencedor y jamás vencido Timonel de Carcajona, [...] que viene armado con las armas partidas a cuarteles: azules, verdes, blancas y amarillas, y trae en el escudo un gato de oro en campo leonado, con una letra que dice: Miau, que es el principio del nombre de su dama que, según se dice, es la sin par Miulina» ${ }^{109}$.

Por su parte, el linajudo y desengañado Quevedo truena contra los ambiciosos que se ufanan de descender de los godos y los evocan en sus blasones, pero no imitan las gestas de quienes habían teñido de azul su sangre roja ${ }^{110}$.

No obstante, es en la novela picaresca desde donde se redoblan las invectivas $^{111}$. La pícara Justina compendia toda una batería de recursos subversivos del orden estamental ${ }^{12}$, trufando el discurso de su vida con asertos como «todos se salen con poner las armas que pueden pagar» ${ }^{113}$.

Precisamente sobre los fraudes heráldicos, denuncia este mismo autor que «Nadie hay que tenga licencia para pintar armas en su casa, que no ponga un castillo y un león, que para esto basta ser castellano o leonés ${ }^{114}$. Así, López de Úbeda narra el cuento de un pícaro sastre apellidado Pimentel que colocó una piedra armera en el umbral de su casa con el escudo de los Pimenteles y, siendo requerido por la justicia a que acreditase su blasón, le responde que las veneras que lo adornaban eran las con-

\footnotetext{
${ }^{109}$ Cervantes Saavedra, 1605, I, 18.

${ }^{110}$ «Los vanos y poderosos, por defuera resplandecientes y dentro pálidos y tristes» publicada en $E l$ Parnaso español se dice «Las descendencias gastan muchos godos; / todos blasonan, nadie los imita, / y no son sucesores, sino apodos», vv. 112-114.

${ }^{111}$ Valle Porras, 2016.

${ }^{112}$ Jones, 1974; Torres, 2000; Oltra Tomás, 1999.

${ }^{113}$ Una velada crítica a los blasones contrahechos y a la venta de honores. Su trasfondo histórico en Domínguez Ortiz, 1976, pp. 4-8.

${ }^{114}$ López de Úbeda, 2005, p. 140.
} 


\section{LA HERÁLDICA DEL PODER: LOS EMBLEMAS DE LA NOBLEZA ESPAÑOLA}

chas que traía de sus peregrinaciones a Compostela, saliendo airoso del aprieto.

En otra novela del mismo género, la Vida de don Gregorio Guada$\tilde{n} a$, el protagonista habla de sus antepasados en los siguientes términos caricaturescos:

Estos fueron los más honrados de mi linaje, de cuyos oficios saqué mis armas. Bien podía mi vanidad pintar en su escudo zorras, zorrillas, perros, gavilanes, castillos y otras sabandijas; pero sería igualarme y aun condenarme por la vía ordinaria. La guadaña y el orinal saqué de mi padre, las muelas de mi tío, las redomas de mi boticario, y a este paso los demás con que adorno el escudo de mis armas ${ }^{115}$.

Por su parte, en Periquillo el de las Gallineras se reproducen las sátiras contra los poderosos: «un caballero entendido, abriendo sus armas, que se componían de un gavilán en cuya cabeza se sentaba una mariposa, mandó que al gavilán le pintasen sin uñas y una letra que dijese: No te ofenderá mi pico, que, aunque pico, es reportado; / ni mis uñas, porque me las he cortado ${ }^{116}$. En este contexto, el gavilán simbolizaba la codicia o la usura frente nobleza del halcón (el ave de cetrería caballeresca por excelencia); mientras que la mariposa evocaba la metamorfosis de villano a noble. Sin embargo, poco después, refuerza la asociación nobleza y caridad cuando afirma que «El que rubrica sus armas con la sangre del pobre ya no es hidalgo, ni aún algo ${ }^{117}$.

Pero una cosa era satirizar sobre los desórdenes morales o estamentales y otra, muy distinta, lanzar andanadas contra aristócratas con nombres y apellidos. Es el caso de Vélez de Guevara, jugador de ventaja, que una vez caído el vilipendiado valido duque de Lerma en su obra El diablo cojuelo (1641), cuando sobrevuela por algunas poblaciones andaluzas, alude a la ciudad de «Lucena, del Alcaide de los Donceles, Duque de Cardona, en cuyo océano de blasones se anegó la gran casa de Lerma» ${ }^{118}$.

En esta senda, es excepcional localizar sonetos vilipendiando a media constelación aristocrática castellana, como sucede en la segunda mitad del siglo XVII cuando un poeta anónimo compone un soneto intitulado Al feliz consorcio de los excelentísimos señores Condes de Tendilla,

\footnotetext{
${ }^{115}$ Enríquez Gómez, El siglo pitagó rico , pp. 146-147.

${ }^{116}$ Santos, 2013, p. 302.

${ }^{117}$ Santos, 2013, p. 317.

${ }^{118}$ Vélez De Guevara, El diablo cojuelo, p. 119.
} 


\section{MIGUEL FERNANDO GÓMEZ VOZMEDIANO}

que se conserva en la Biblioteca Nacional de Lisboa, y donde saca a relucir todos los trapos sucios de algunos de los linajes castellanos viejos (Mendoza y Velasco) y nuevos (Ibáñez de Segovia), con insinuaciones a infidelidades, homosexualidad, virgos remendados y bodas por interés, haciendo «equívocos al mundo sus blasones» ${ }^{119}$.

Incluso un género tan popular como la paremiología se acuerda de los escudos de armas para criticarlos, con adagios tales como «Doblones pintan blasones» o «Escudos pintan escudos» o «Bien de escudos y blasones, pero mal de pantalones ${ }^{120}$. Juan de Mal Lara, al explicar el refrán «Dejemos padres y abuelos, por nosotros seamos buenos» comenta: «este consejo es para los que gastan su tiempo en contar sus linajes, el buscar el blasón de sus armas, en escrebir los árboles de su genealogía, en estar más cerca de Jasón o de Hércules y con esto quedan contentos», una idea que refuerza al glosar otro refrán: «al hombre bueno no se le busque abolengo» ${ }^{121}$.

\section{EPÍLOGO. EL FIN DE LA ERA DE LA NOBLEZA}

Las tornas parecían cambiar con la eclosión primero de la Ilustración y luego de la España Liberal, esbozándose una subversión de valores que no tuvo continuidad. A inicios del siglo XIX, en plena fiebre constitucionalista, la incipiente prensa crítica la actitud de muchos nobles que murmuran contra la Pepa, la Constitución de 1812, reproduciendo un monólogo tan delirante, que buscaba la complicidad del lector doceañista:

en este mundo no todos pueden ser iguales; yo, que desciendo en línea recta de las pirámides de Egipto, según me dijo varias veces mi ayo; que en mi escudo de armas en campo de oro tengo dos avestruces, gules, y seis calderas, y por cimera un mico; que tengo aquí tantos cortijos, acullá tantos; que soy un señor de tantos timbres, que tenía el derecho de nombramientos (o lo hacía mi mayordomo que es lo mismo) que para mí pesaban, para mí araban, para mí cazaban y para mí podaban viñas, y yo mientras jugaba y triunfaba ${ }^{122}$.

\footnotetext{
${ }^{119}$ Cortijo Ocaña, 2002, pp. 259-263.

${ }^{120}$ Álvarez Díaz, 2010.

${ }^{121}$ Mal Lara, 1568, fol. 183r y 276r

${ }^{122}$ Firmado G.S. (anónima, solo iniciales), El redactor general, 409. 27/07/1812, Cádiz.
} 


\section{LA HERÁLDICA DEL PODER: LOS EMBLEMAS DE LA NOBLEZA ESPAÑOLA}

Lo cierto fue que la abolición del Antiguo Régimen puso a la nobleza de sangre en el disparadero, debiendo acreditar derechos y propiedades, para lo cual revolvió archivos y se vio obligada a acudir a los tribunales. En plena ofensiva antiseñorial, la prensa liberal se volcó en una campaña para desacreditar los símbolos aristocráticos en crisis:

Todos los privilegios desaparecieron, y no les queda otro que el de guardar sus pergaminos, poner el escudo de sus armas pintado al óleo en la antesala, grabarlo en las tarjetas, en el ángulo izquierdo del papel de cartas y en el sortijón del índice de la mano izquierda, con arreglo a la última $\operatorname{moda}^{123}$.

Ante este ataque directo a su línea de flotación, una clase social en pleno proceso de reinvención reaccionó, uniendo su destino a la monarquía borbónica, acogiendo en su seno a la alta burguesía y reproduciendo sus valores culturales mediante recursos modernos. No es casualidad que sea en el arranque de la Década Moderada cuando se publique El blasón español o Ciencia heráldica (1845), escrita por Ramón Medel y que contenía 40 láminas litografiadas a todo color, que podía comprarse mediante suscripción en 20 entregas; $y$, por entonces, también se imprimió el semanario El trono y la nobleza (Madrid, 1846-1858), una lujosa revista cuya suscripción costaba 90 reales por trimestre. Además, es precisamente por entonces cuando se detectan los primeros bibliófilos y coleccionistas de documentos genealógicos; por ejemplo, mediado el siglo XIX nos hallamos con la noticia de que, en la ciudad de Valencia, «El Dr. D. Juan Bernardón, posee una rica colección de manuscritos e impresos de heráldica, y una copiosa, rara y singular colección de árboles genealógicos de estimable valor ${ }^{124}$. No en vano nos hallamos ante la centuria de los historiadores.

La I República asistió al recrudecimiento de las invectivas antinobiliarias, como demuestran el raudal de caricaturas mordaces publicadas en la prensa decimonónica, donde los blasones evocan las ínfulas de ennoblecimiento de la casta política o el poder residual en manos de los antiguos señores, convertidos ahora en señoritos. Asimismo, también en novelas costumbristas como «Blasones y talegas» ${ }^{125}$, se incidía en la co-

\footnotetext{
${ }^{123}$ El Corresponsal (Madrid). 2/10/1842, p. 4.

${ }^{124}$ Boix, Manual del viajero.

${ }^{125}$ Pereda, Tipos y paisajes.
} 


\section{MIGUEL FERNANDO GÓMEZ VOZMEDIANO}

munidad de intereses entre la burguesía y las viejas estirpes, siendo la mujer el principal vehículo de ascensión social de los nuevos ricos ${ }^{126}$.

Años después, la Restauración borbónica en España supuso un repunte en los ideales nobiliarios, pero ya era demasiado tarde. La Generación del 98 fue cronista de la decadencia de esta clase social y del ocaso de toda una época ${ }^{127}$. En la escena internacional las dos guerras mundiales acabaron con los últimos rescoldos de sus rancios privilegios, considerados anacrónicos ${ }^{128}$. La modernidad había triunfado, aunque la nobleza todavía persistía, cada vez más permeable a los códigos capitalistas y burgueses, y a las mutaciones sociales y económicas de su tiempo.

\section{BIBLIOGRAFÍA}

Alós Fontcuberta, Francisco de, Lemas heráldicos españoles, Madrid, Hidalguía, 1961.

Álvarez Díaz, Juan José, «Escuderos e hidalgos en los refranes españoles», Paremia, 19, 2010, pp. 29. 40 .

Álvarez-Ossorio Alvariño, A., «Rango y apariencia. El decoro y la quiebra de la distinción en Castilla (ss. XVI-XVII)», Cuadernos de Historia Moderna, 17, 1998-1999, pp. 263-278

Antonio, Agustín, Diálogos de las armas y linajes de la nobleza de España, Madrid, Juan de Zúñiga, 1734.

Aponte, Vasco de, Recuento de las casas antiguas del reino de Galicia, Santiago de Compostela, Xunta de Galicia, 1984.

Arellano, Ignacio, "Cultura visual y emblemática en las Novelas ejemplares de Cervantes», Anales Cervantinos, 45, 2013, pp. 93-108.

Argote de Molina, Gonzalo, Nobleza de Andalucía, Sevilla, Fernando Díaz, 1588.

Arias Nevado, Javier, «El papel de los emblemas heráldicos en las ceremonias funerarias en la edad media (ss. XIII-XV)», en Estudios de genealogía, heráldica y nobiliaria, coord. Miguel Ángel. Ladero Quesada, Madrid, Universidad Complutense, 2006, pp. 49-79.

Ballarín Domingo, Pilar, La educación de las mujeres en la España contemporánea (siglos XIX y XX), Madrid, Síntesis, 2001.

Belmas, Elisabeth, Jouer autrefois. Essai sur le jeu dans la France Moderne (XVI'-XVIII siècles), Paris, Seysell-Champ Vallon, 2006.

Beltrán-Quera, Miguel, La pedagogía de los jesuitas en la "Ratio Studiorum", San Cristóbal, Universidad de Táchira-Andrés Bello, 1984.

Boix, Vicente, Manual del viajero y guía de forasteros de Valencia, Valencia, José Rius, 1849.

Bouza Álvarez, Fernando Jesús, Palabra e imagen en la Corte, cultura oral y visual de la nobleza en el Siglo de Oro, Madrid, Abada Editores, 2003.

Burke, Peter, Visto y no visto. El uso de la imagen como documento histórico, Madrid, Crítica, 2001.

Cadenas y Vicent, Vicente de, Repertorio de blasones de la comunidad hispánica, Madrid, Hidalguía, 1964-1969, 4 vols.

Cadenas y Vicent, Repertorio de blasones de la comunidad hispánica: letras A-B-C-CH, Madrid Hidalguía, 1987.

${ }^{126}$ Ballarín Domingo, 2001, p. 249.

${ }^{127}$ Valle-Inclán, Águila de Blasón.

${ }^{128}$ Hermosilla, 2011. 


\section{LA HERÁLDICA DEL PODER: LOS EMBLEMAS DE LA NOBLEZA ESPAÑOLA}

Calderón Ortega, José Manuel, «Memoria familiar e historia de la Memoria. El archivo de la Casa de Alba», en Nobilitas: estudios sobre la nobleza y lo nobiliario en la Europa Moderna, coord. Juan Hernández Franco, José Antonio Guillén Berrendero, Santiago Martínez Hernández, Madrid, Doce Calles, 2014, pp. 177-202.

Carrillo Castillo, Jesús, «Cultura cortesana e imperio: el Libro del blasón, de Gonzalo Fernández de Oviedo", Locvs Amoenvs, 4, 1998-1999, pp. 137-154.

Castillo Solórzano, Alonso de, Aventuras del bachiller Trapaza, Zaragoza, Pedro Vergés, 1637.

Ceballos-Escalera y Gila, Alfonso de (marqués de la Floresta), «El rey de armas Diego de Urbina, Regidor de Madrid», Anales de la Real Academia Matritense de Heráldica y Genealogía, 2, 1992- 1993, pp. 113-136.

Ceballos-Escalera y Gila, Alfonso de (marqués de la Floresta), Heraldos y Reyes de Armas en la corte de España, Madrid, Prensa y Ediciones Ibero-Americanas, 1993.

Cervantes Saavedra, Miguel de, El ingenioso hidalgo Don Quijote de la Mancha, Madrid, Juan de la Cuesta, 1605.

Chartier, Roger, El mundo como representación. Historia cultural: entre práctica y representación, Barcelona, Gedisa, 1992.

Comella y Vilamitjana, Luciano Francisco, «Nobleza. Sueño Moral (Rasgo moral)», en Correo de Madrid (o de los ciegos), Madrid, Josef Herrera, 1787, I , pp. 1-7, 20/10/1786.

Cortijo Ocaña, Antonio, «Notas para un soneto contra las casas de Mendoza, Ibáñez de Segovia y Velasco", eHumanista, 2, 2002, pp. 259-263.

Coss, Peter R. y Maurice Hugh Keen (eds.), Heraldry, Pageantry and Social Display in Medieval England, Woodbridge, The Boydel Press, 2002.

Díaz Gito, Manuel Antonio, «Encomio de Mateo Vázquez y heráldica de los Lecca en La Corsica de Calvete de Estrella", Talia Dixit, 9, 2014, pp. 73-95.

Díaz Rodríguez, Antonio, «La instrumentalización de los cabildos catedrales. Los Salazar como estudio de caso de la minoría judeoconversa», en Iglesia, poder y fortuna: clero y movilidad social en la España moderna, ed. Enrique Soria Mesa y Antonio José Díaz Rodríguez, Granada, Comares, 2012, pp. 115-138.

Domínguez Ortiz, Antonio, «Comercio y blasones. Concesiones de hábitos de Órdenes Militares a miembros del Consulado de Sevilla en el siglo XVII», Anuario de Estudios Americanos, 33, 1976, pp. 4-8.

Domínguez Ortiz, Antonio, La sociedad española en el siglo XVII el estamento nobiliario, Madrid, CSIC., 1992, 2 vols.

Duque de Estrada y Castañeda, María Dolores, «El negocio de la heráldica en Internet», Anales de la Real Academia Matritense de Heráldica y Genealogía, 8/1, 2004, pp. 355-366.

Egido, Aurora, «Linajes de burlas en el Siglo de Oro», en Studia Aurea. Actas del III Congreso Internacional de la AISO (Toulouse, 1993). I. Plenarias. General. Poesía, ed. Ignacio Arellano, Carmen Pinillos, Fréderic Serralta y Marc Vitse, M., Pamplona-Toulouse, GRISO-LEMSO, 1996, pp. 19-50.

Egido, Aurora, De la mano de Artemia. Estudios sobre Literatura, Emblemática, Mnemotecnia y Arte en el Siglo de Oro, Barcelona, Olañeta, 2004.

Elias, Norbert, Il processo di civilizzazione, Bologna, Il Mulino, 1988.

Enríquez Gómez, Antonio, El siglo pitagórico y Vida de don Gregorio Guadaña, ed. Teresa de Santos, Madrid, Cátedra, 1991.

Escalera Pérez, Reyes y Esther Galindo Blasco, «¿Olvido o memoria? La muerte y la fama en las ceremonias fúnebres y en los libros de emblemas?», en España festejante. El siglo XVIII, ed. Margarita Torrione, Málaga, Diputación de Málaga, 2000, pp. 543-554.

Esteban Llorente, Juan Francisco, «El influjo de la emblemática en el arte aragonés», en Emblemata Aurea: La emblemática en el arte y la literatura del Siglo de Oro, Madrid, Akal, 2010.

Fernández de Bethencourt, Francisco, Historia Genealógica y heráldica de la Monarquía española, Casa Real y Grandes de España, imprenta de Enrique Teodoro, Madrid, 1897-1920, 10 vols.

Fernández del Hoyo, Manuel, De Portugal a Castilla: creación y recreación de la memoria linajística en la casa condal de Benavente, Madrid, Universidad Complutense de Madrid, 2013. 


\section{MIGUEL FERNANDO GÓMEZ VOZMEDIANO}

Ferrari, Matteo (ed.), L'arme segreta. Araldica e storia dell'arte nel Medioevo (secoli XIII-XV), Firenze, Le Lettere, 2015.

García Carraffa, Arturo, Diccionario Hispanoamericano de Heráldica, Onomástica y Genealogía, ed. Endika de Mogrobejo, Bilbao, Editorial Mogrobejo-Zabala, 1996-2017, 11 vols.

García Carraffa, Alberto y Arturo García Carraffa, Enciclopedia heráldica y genealógica hispanoamericana, Madrid, Antonio Marzo, 1919-1968, 88 vols.

García Cubero, Luis, Bibliografía Heráldico-Genealógica-Nobiliaria de la Biblioteca Nacional: (Manuscritos), Madrid, Biblioteca Nacional, 1992.

García Cubero, Luis, Bibliografía heráldico-genealógico-nobiliaria de la Biblioteca Nacional: (impresos) (1959-1994), Madrid, Biblioteca Nacional, 1995.

García Hernán, David, La aristocracia en la encrucijada: la alta nobleza y la monarquía de Felipe II, Córdoba, Universidad de Córdoba, 2000.

García Hernán, David y Miguel Fernando Gómez Vozmediano, La cultura de la sangre en el Siglo de Oro. Entre literatura e historia, Madrid, Sílex, 2016.

Gómez Vozmediano, Miguel Fernando, «Archivos Nobiliarios Españoles: pasado, presente y ifuturo? Tipología documental e investigación modernista», en Los señoríos en la Andalucía Moderna. El Marquesado de los Vélez, coord. Francisco Andújar Castillo y Julián Pablo Díaz López, Almería, Instituto de Estudios Almerienses, 2007, pp. 129-210.

Gómez Vozmediano, Miguel Fernando, «Espacios de poder y pugna de vanidades: litigios por cuestiones heráldicas en la Castilla de los Austrias», en Comercio y Cultura en la Edad Moderna ed. Juan José Iglesias Rodríguez, Rafael M. Pérez García y Manuel F. Fernández Chaves, Sevilla, Editorial Universidad de Sevilla, 2015, pp. 2634-2645.

Gracián, Baltasar, «Agudeza y arte de ingenio», en Obras completas, ed. Arturo del Hoyo, Madrid Aguilar, 1967.

Guerra y Villegas, José Alfonso, Discurso histórico político sobre el origen y preeminencias de el oficio de heraldos, reyes de armas, feciales y caduceadores, Madrid, Imprenta Real, 1693.

Guillén Berrendero, José Antonio, «Blasones y esmaltes: Don Juan Alfonso de Guerra y Sandoval y el oficio de Rey de Armas», en Las élites en la época moderna: la monarquía española, coord. Enrique Soria Mesa, Juan Jesús Bravo Caro y José Miguel Delgado Barrado, Córdoba, 2009, IV, pp. 185-204.

Guillén Berrendero, José Antonio, «lluminando las sombras: Diego Barreiro, un Rey de Armas en la Corte de Felipe IV", Libros de la Corte, 2, 2010, pp. 15-20.

Guillén Berrendero, José Antonio, «Gritos, honras y blasones: el papel de los Reyes de Armas durante el reinado de Felipe V», en Crisis del modelo cortesano, coord. José Martínez Millán, Concepción Camarero Bullón y Marcelo Luzzi Traficante, Madrid, Polifemo, 2013a, II, pp. 1093 1125.

Guillén Berrendero, José Antonio, «Un oficio de la memoria honrada de la Monarquía: los reyes de armas y la idea de nobleza en Castilla en el siglo XVI», Armas e Troféus. Revista de Historia, Heráldica, Genealogía e arte, 9, 2013b, pp. 481-503.

Guillén Berrendero, José Antonio, «Conocimiento, prestigio y blasones: reyes de armas e informantes de las órdenes militares ante el problema del honor y la común opinión en la castilla del seiscientos", Magallánica, 2, 2015a, pp. 30-60.

Guillén Berrendero, José Antonio, «Reyes de armas, blasones y discursos: algunas notas en torno a los conflictos sobre la nobleza y su definición en el Barroco", Atalanta. Revista de las letras barrocas, 3/1, 2015b, pp. 53-95.

Guillén Berrendero, José Antonio, «Reyes de armas, nobiliarios y armerías en el confuso horizonte discursivo de la corte madrileña del Seiscientos. Una nota y un ejemplo», en La Corte del Barroco: Textos literarios, avisos, manuales de corte, etiqueta y oratoria, coord. Antonio Rey Hazas, Mariano de la Campa Gutiérrez y Esther Jiménez Pablo, Madrid, Polifemo, 2016, pp. 483-513.

Guillén Berrendero, José Antonio, «Bibliotecas e brasões na cultura nobiliárquica: livros e conhecimento heráldico da nobreza castelhana nos séculos XVI-XVII», Livrarias nobiliárquicas no es- 


\section{LA HERÁLDICA DEL PODER: LOS EMBLEMAS DE LA NOBLEZA ESPAÑOLA}

paço ibérico. Entre a Idade Média e o Renacimiento, Lisboa, Universidade Nova de Lisboa, 2016 [en prensa].

Guillén Berrendero, José Antonio y Manuel Amador González Fuertes (eds.), Nobiliario. Sancho Busto de Villegas, Murcia, Universidad de Murcia, 2014.

Hermosilla, Luis, «Representación burlesca de los Blasones en Gran Señor y Rajadiablos», Revista Chilena de Literatura, 80, 2011, pp. 171-183.

Herrera Casado, Antonio, El palacio del Infantado en Guadalajara, Guadalajara, Institución Provincial de Cultura Marqués de Santillana, 1975.

Jones, Joseph R., «Hieroglyfics en La Pícara Justina», en Estudios literarios de hispanistas norteamericanos dedicados a Helmut Herzel con motivo de su ochenta aniversario, Barcelona, 1974 pp. $415-429$

Labrador, Carmen, El sistema ed ucativo de la Compañía. La Ratio Studiorum, Madrid, UPCO, 1992.

Lasso de la Vega y López de Tejada, Miguel (marqués del Saltillo), Historia nobiliaria española (contribución a su estudio), Madrid, Editorial Maestre, 1951-1953, 2 vols.

Layna Serrano, Francisco, Historia de Guadalajara y sus Mendozas en los siglos XV y XVI, Madrid, Aldus, 1942, 4 vols.

Lope de Vega, «El blasón de los Chaves de Villalba» en Comedias de Lope de Vega, coord. Ramón Valdés y María Morrás, Lleida, Milenio, 2010, Parte X, 3.

Lope de Vega, La vega del Parnaso, ed. Felipe B. Pedraza Jiménez y Pedro Conde Parrado, Cuenca, Universidad de Castilla-La Mancha, 2015.

López Alemany, Ignacio, «"Lengua spada" y "buen palacio” en los motes eróticos y burlescos de $E l$ cortesano de Luis Milán", La corónica 38/1, 2009, pp. 315-331.

López Fanjul de Argüelles, Carlos, Águilas, lises y palmerines. Orígenes y evolución de la heráldica asturiana, Gijón, Trea, 2008.

López-Fanjul de Argüelles, Carlos, «Las armerías de los conquistadores de Indias», Histo ria y Genealogía, 4, 2014, pp. 151-178.

López Fanjul de Argüelles, Carlos, «La imaginación heráldica en la España del siglo XVI. Las armerías de los caciques y los muebles americanos", Histo ria y Genealogía, 5, 2015, pp. 233-272.

López Poza, Sagrario, «Las empresas de Giacomo Saporiti a las heroicas hazañas del duque de Osuna, virrey de Sicilia», en Imagen y Cultura. La interpretación de las imágenes como Historia cultural, ed. Rafael García Mahíques y Vicent Francesc Zuriaga Senent, Valencia, Biblioteca Valenciana, 2008a, II, pp. 973-988.

López Poza, Sagrario, «Uso político de la emblemática en la España de los siglos XVI y XVII», Con parola brieve e con figura. Emblemi e imprese fra antico e moderno, ed. Lina Bolzoni y Silvia Volterrani, Pisa, Normale, 2008b, pp. 371-419.

López Poza, Sagrario, «Signos visuales de identidad en el Siglo de Oro", Compostella Aurea. Actas del VIII Congreso de la AISO, coord. Santiago Fernández Mosquera, Santiago de Compostela, Universidad de Santiago, 2011, I, pp. 61-94.

López de Úbeda, Francisco, Libro de entretenimiento de la pícara Justina, León, Lobo Sapiens, 2005.

Lozano López, Juan Carlos, «La cultura simbólica en el Barroco», en El recurso a lo simbólico: reflexiones sobre el gusto II, coord. Ernesto Carlos Arce Oliva, Alberto Castán Chocarro y Concha Lomba Serrano, Zaragoza, Institución Fernando el Católico, 2014, pp. 67-89.

Mal Lara, Juan de, La Philosophia vulgar, Sevilla, Hernando Díaz, 1568.

Martinena Ruiz, Juan José (ed.), Libro de armería del Reino de Navarra. Pamplona, Diputación Foral de Navarra-Institución Príncipe de Viana, 1982.

McCready, Warren Thomas, La heráldica en las obras de Lope de Vega y sus contemporáneos, Toronto, University of Toronto, 1962.

Medel, Ramón, El blasón español o la ciencia heráldica. Escudos de armas de los diferentes reinos en que se ha dividido España, y de las familias nobles de la misma, Barcelona, J. Guerrero, 1845.

Menéndez Pidal de Navascués, Faustino (ed.), El libro de la cofradía de Santiago de Burgos, Bilbao La Gran Enciclopedia Vasca, 1977. 


\section{MIGUEL FERNANDO GÓMEZ VOZMEDIANO}

Menéndez Pidal de Navascués, Faustino, «Armoiries non nobles en Espagne», en Les armoirires non nobles en Europe: XIII'-XVIII siècles. III' Colloque International d'Héraldique, coord. Hervé Pinoteau, Michel Pastoureau y Michel Popoff, Paris, Leopard d'Or, 1986, pp. 95-104.

Menéndez Pidal de Navascués, Faustino, «Heráldica funeraria en Castilla», en Leones y castillos. Emblemas heráldicos en España, Madrid, Real Academia de la Historia, 1999, pp. 147-162.

Menéndez Pidal de Navascués, Faustino, «Prólogo» en Carlos López Fanjul de Argüelles, Águilas, lises y palmerines. Orígenes y evolución de la heráldica asturiana, Gijón, Trea, 2008.

Menéndez Pidal de Navascués, Faustino, Los emblemas heráldicos. Novecientos años de historia, Sevilla, Real Maestranza de Caballería de Sevilla, 2014.

Ménestrier, Claude-François, Abbrégé méthodique des principes héraldiques, ou du véritable art du blason, Lyon, Benoît Coral, 1661.

Ménestrier, Claude-François, L'Art des emblèmes, Lyon, Benoît Coral, 1662.

Ménestrier, Claude-François, Le chemin de l'honneur. Jeu d'armoiries, Lyon, Benoît Coral, 1672.

Ménestrier, Claude-François, Les diverses especes de noblesse, et les manieres d'en dresser les preuves, Paris, Chez R. J. B. de la Caille, 1682.

Ménestrier, Claude-François, Des Décorations funèbres, où il est amplement traité des tentures, des lumières, des mausolées, catafalques, inscriptions et autres ornemens funèbres, Paris, de La Caille, 1683.

Ménestrier, Claude-François, L'art des Emblèmes, où s'enseigne la morale par les figures de la fable, de l'histoire, $\mathcal{E}$ de la nature, Paris, de La Caille, 1684.

Ménestrier, Claude-François, La méthode du blason, Paris, Michallet, 1689.

Ménestrier, Claude-François, Jeu de cartes du blason, Lyon, Thomas Amaulry, 1692.

Mínguez Cornelles, Víctor Manuel, «Imágenes para leer, Función del grabado en el libro del Siglo de Oro», en Escribir y leer en el siglo de Cervantes, comp. James S. Amelang y Antonio Castillo Gómez, Barcelona, Gedisa, 1999, pp. 255-283.

Neubecker, Ottfried, Le grand livre de l'héraldique. L'histoire l'art et la science du blason, ParisBruxelles, Elsevier Séquoia, 1977.

Olarán Múgica, Clotilde, "Consideraciones sobre el mal uso de la Heráldica y la Genealogía», Euskonews \& Media, 11, 1999, pp. 12-19.

Oltra Tomás, José Miguel, «Los emblemas de la pícara Justina. El caso de la "Introducción General"», Voz y letra. Revista de literatura, 10/1, 1999, pp. 51-70.

Ortega y Gasset, José, «Notas del vago estío», en El Espectador. V. Notas del vago estío, vitalidad, alma, espíritu, fraseología y sinceridad, Madrid, Revista de Occidente, 1927, pp. 76-82.

Ortiz Rodríguez, Mayra, «Lope de Vega y la Emblemática: entre la tradición y la innovación», en IV Congreso Internacional de Letras, Transformaciónes culturales. Debates de la teoría, la crítica y la lingüística, Barcelona, Universitat Autónoma, 2012, pp. 1547-1555.

Oteiza, Blanca, "Aspectos emblemáticos y pictóricos en el teatro de Tirso de Molina», en Tirso de Molina: textos e intertextos. Actas del Congreso Internacional organizado por el GRISO y la Universidad de Parma, ed. Laura Dolfi y Eva Galar, Pamplona, Instituto de Estudios Tirsianos, 2002, pp. 57-87.

Pacheco, Francisco, Libro de descripción de verdaderos retratos, ilustres y memorables varones, (Sevilla, 1599), Sevilla, Diputación Provincial de Sevilla, 1985.

Pardo de Guevara y Valdés, Eduardo, «El estudio de los emblemas heráldicos del medievo peninsular. Estado de la cuestión", Hispania, 50, 1990, pp. 1003-1016.

Pastoureau, Michel, Traité d'Héraldique, Paris, A. et J. Picard, 1979.

Pastoureau, Michel, Una historia simbólica de la Edad Media occidental, Buenos Aires, Kate Editores, 2006.

Pedraza Jiménez, Felipe B., Edición crítica de las rimas de Lope de Vega, Cuenca, Universidad de Castilla-La Mancha, 1993.

Pereda, José María de, Tipos y paisajes, Madrid, T. Fontanet, 1871.

Piferrer, Francisco, Nobiliario de los reinos y señoríos de España. Contiene las armas y blasones de los reinos, provincias, ciudades, villas y principales pueblos de España, con todos los apelli- 


\section{LA HERÁLDICA DEL PODER: LOS EMBLEMAS DE LA NOBLEZA ESPAÑOLA}

dos que se encuentran en los tratados de heráldica y nobiliarios más autorizados, Madrid, La Redacción, 1857-1860, 6 vols. [I, II, III, IV, $\underline{\mathrm{V}} \underline{\mathrm{VI}}$ ]

Praz, Mario, Imágenes del Barroco, Madrid, Siruela, 1989.

Quevedo, Francisco de, «Epístola satírica y censoria contra las costumbres presentes de los castellanos, escrita a don Gaspar de Guzmán, conde de Olivares, en su valimiento» en Antología de la poesía en lengua española. Siglos XVI y XVII, ed. María Rosa Palazón et al., México, UNAM, 1999, pp. 134-138.

Quevedo, Francisco de, Parnaso español (sonetos), ed. Ramón García González, Alicante, Biblioteca Virtual Miguel de Cervantes, 2003.

Recopilación de las leyes destos reinos, Alcalá de Henares, Juan Íñiguez de Lequerica, 1598.

Redondo Veintemillas, Guillermo, Alberto Montaner Frutos y María del Carmen García López, (eds.), Actas del I Congreso Internacional de Emblemática General, Zaragoza, AUE./CSIC., 2004, 3 vols.

Rico, Francisco, «Un penacho de penas. De algunas invenciones y letras de caballeros», en Texto y contextos. Estudios sobre la poesía española del siglo XV, ed. Francisco Rico, Barcelona, Crítica, 1990, pp. 189-228.

Riguet, Sébastien, «"Un león por armas tengo, y Benavides se llama”. Retórica, heráldica y blasón en La prudencia en la mujer de Tirso de Molina»", en El hombre histórico y su puesta en discurso en el Siglo de Oro, ed. J. Enrique Duarte e Isabel Ibáñez, New York, Idea, 2015, pp. 165183.

Riquer, Martín de, Heràldica catalana: des l'any 1150 al 1550, Barcelona, Quaderns Crema, 1983.

Rodríguez de la Flor, Fernando, «Los contornos del emblema: del escudo heráldico a la divisa y la empresa», en Emblemas. Lecturas de la imagen simbólica, ed. F. Rodríguez de la Flor, Madrid, Alianza Editorial, 1995.

Rodríguez Rodríguez, Begoña, Antología de la novela picaresca española, Alcalá de Henares, Universidad, 2005.

Santos, Francisco, Periquillo el de las Gallineras, ed. M. Donoso Rodríguez, Nueva York, IDEA, 2013.

Seixas, Miguel Beirao de Almeida: «A compilação de armoriais em livrarias de príncipes e hidalgos portugueses nos séculos XV e XVI», Livrarias nobiliárquicas no espaço ibérico. Entre a Idade Média e o Renacimiento, Lisboa, Universidade Nova de Lisboa, 2016 [en prensa].

Silva y Mendoza, Diego de, Obra Completa. I. Poesía desconocida, ed. Trevor Dadson, Madrid, Real Academia Española, 2016.

Stone, Lawrence, La crisis de la aristocracia, 1558-1641, Madrid, Alianza Editorial, 1985.

Tirso de Molina, Quinta parte de comedias del maestro ..., Madrid, Imprenta Real, 1636.

Tirso de Molina, El amor médico (1620), ed. Blanca Oteiza, Madrid-Pamplona, Instituto de Estudios Tirsianos, 1997.

Torres, Lucas, «Emblemática y literatura: el caso de La pícara Justina», Actas del XIII Congreso de la Asociación Internacional de Hispanistas, Madrid, Castalia, 2000, I, pp. 780-789.

Trambaioli, Marcella, «Lope de Vega y la casa de Moncada», Criticón, 106, 2009, pp. 5-44.

Vaivre, Jean-Bernard de y Léon Jéquier, Elements d héraldique médievale: Orientation pour l'étude et l'utilisation des armoriaux du Moyen Âge, Paris, Centre National de la Recherche Scientifique, 1975.

Valero de Bernabé Martín de Eugenio, Luis, Análisis de las características generales de la heráldica gentilicia española y de las singularidades heráldicas existentes entre los diversos territorios históricos hispanos, Madrid, Universidad Complutense, 2007.

Valle Porras, José Manuel, «La heráldica española de la edad moderna y su percepción en la novela picaresca (1554-1668)", Historia y Genealogía, 6, 2016, pp. 251-299.

Valle Porras, José Manuel, Usos sociales de la heráldica castellana durante la Edad Moderna (siglos XVI-XIX). Estudio del caso de la ciudad de Lucena (Córdoba), Córdoba, Universidad de Córdoba, 2017.

Valle-Inclán, Ramón del, Águila de Blasón (1907), ed. Antón Risco, Madrid, Espasa-Calpe, 1994.

Valverde Ogállar, Pedro, Manuscritos y heráldica en el tránsito a la modernidad: el libro de armería de Diego Hernández de Mendoza, Madrid, Universidad Complutense, 2004. 


\section{MIGUEL FERNANDO GÓMEZ VOZMEDIANO}

Vega García-Luengos, Germán, El Cid en el teatro del Siglo de Oro español. Las múltiples caras de una figura persistente, Burgos, Instituto Castellano y Leonés de la Lengua, 2007.

Velasco Maíllo, Honorio Manuel, Cuerpo y Espacio: Símbolos y metáforas representación y expresividad en las culturas, Madrid, Ramón Areces, 2007.

Vélez de Guevara, Luis, El diablo cojuelo, Madrid, Espasa-Calpe, 1969.

Vélez de Guevara, Luis, El Alba y el Sol (c. 1613), ed. William R. Manson y C. George Peale, Newark, Juan de la Cuesta, 2010.

Yarza Luaces, Joaquín, «La ilustración en el códice de la Cofradía del Santísimo y de Santiago, en Burgos", Locvs Amoenvs, 1, 1995, pp. 7-32.

Zafra, Rafael, y José Javier Azanza (eds.), Emblemata aurea. La emblemática en el Arte y la Literatura del Siglo de Oro, Madrid, Akal, 2000.

Zapata de Chaves, Luis, Carlo famoso, Valencia, Joan Mey, 1566.

Zugasti, Miguel, «Órbitas del poder, encargo literario y drama genealógico en el Siglo de Oro: de Encina a Lope de Vega», en El drama histórico. Teoría y comentarios, ed. Kurt Spang, Pamplona, Eunsa, 1998, pp. 129-157.

Zugasti, Miguel y Antonio Cortijo Ocaña, «La Comedia de la sortija (Monforte de Lemos, 1594)», en Tiempo e historia en el teatro del Siglo de Oro, dirs. Isabelle Rouane Soupault y Philippe Meunier, Aix-en-Provence, Presses Universitaires de Provence, 2015, pp. 450-464. 